CENTRO UNIVERSITÁRIO DE BRASÍLIA - UniCEUB

FACULDADE DE CIÊNCIAS DA EDUCAÇÃO E DA SAÚDE - FACES

PROGRAMA DE INICIAÇÃO CIENTÍFICA

CAMILA ZACARIAS LIMA ARAUJO

O TDAH E AS PRODUÇÕES SUBJETIVAS DA CRIANÇA:

PROBLEMATIZANDO O DIAGNÓSTICO COM PAIS E PROFESSORES

BRASÍLIA- DF 


\section{Unc $=0 B$ \\ Centro Unıversıtárıo de Brasílıa}

CAMILA ZACARIAS LIMA ARAUJO

\section{O TDAH E AS PRODUÇÕES SUBJETIVAS DA CRIANÇA: PROBLEMATIZANDO O DIAGNÓSTICO COM PAIS E PROFESSORES}

Relatório final de pesquisa de Iniciação Científica apresentado à Assessoria de Pós-Graduação e

Pesquisa pela Faculdade de Ciências da

Educação e da Saúde - FACES

Orientação: Profa Dra. Luciana Campolina de Oliveira 


\title{
O TDAH e as produções subjetivas da criança: problematizando o diagnóstico com pais e professores
}

\author{
Camila Zacarias Lima Araujo - UniCEUB, PIBIC-CNPq - aluno bolsista \\ camilazaraujo@hotmail.com
}

\section{Luciana de Oliveira Campolina - UniCEUB, professor orientador}

campolina.Iuciana@gmail.com

O presente trabalho problematiza o tema da medicalização e patologização de crianças em contextos escolares quando há manifestação de dificuldades no processo de aprendizagem. Aprofundar a investigação na forma como se configura para a criança esse cenário atual de banalização dos diagnósticos, da aceitação dos sistemas e estruturas escolares e da responsabilização da criança pelo seu fracasso escolar, a partir de uma visão subjetiva e singular é de extrema importância. Assim, propõe-se compreender as produções subjetivas das crianças que receberam o diagnóstico do transtorno de déficit de atenção e hiperatividade (TDAH), analisando suas relações em contexto escolar a partir da Epistemologia Qualitativa e do método construtivo-interpretativo, proposto por González Rey, enfatizando as produções simbólico-emocionais que constituem as experiências da criança em diferentes espaços sociais. Essa concepção epistemológica e proposta metodológica parte da ideia de que o conhecimento é uma produção teórica que implica as ideias do pesquisador acerca das informações produzidas no curso da pesquisa. Portanto, a comunicação entre pesquisador e participantes tem um papel central na geração de espaços dialógicos que favoreçam a expressão subjetiva dos processos estudados. Tendo isso em vista, a pesquisa foi realizada com duas crianças de uma escola pública do Ensino Fundamental, com diagnóstico de TDAH, buscando compreender os aspectos da subjetividade individual e social, envolvidos nas suas experiências escolares e os impactos do diagnóstico para sua aprendizagem, em sua dimensão subjetiva. Também participaram da pesquisa, a professora da sala de aula e os responsáveis da criança. A partir de dinâmicas conversacionais, da análise de documentos e da participação das pesquisadoras na escola, foram construídos indicadores sobre como se configura para a criança o seu modo de aprender dentro da subjetividade social da escola. Um indicador elaborado diz respeito à demasiada importância dada aos diagnósticos e aos laudos psicológicos que mantém constantemente uma relação recursiva com as situações de aprendizagem da criança. Outros indicadores permitiram elucidar que os sentidos subjetivos destas crianças estão perpassados por uma busca de aceitação e de pertencimento à escola, e por sentimentos de insegurança e descrença por parte dos adultos, além de estarem articulados aos sentidos subjetivos da professora acerca do seu papel como educadora. Dessa forma, ressalta-se a relevância de uma reflexão crítica e 
intervenção na vida cotidiana da criança na escola com foco na subjetividade e singularidade para a emergência de sujeitos ativos e transformadores.

Palavras-chave: TDAH, subjetividade, sentidos subjetivos, diagnóstico, aprendizagem 


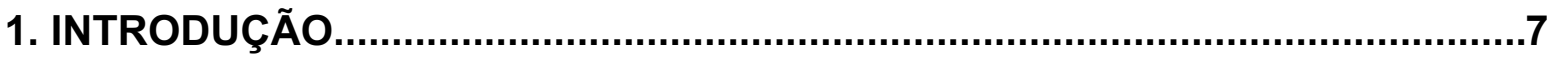

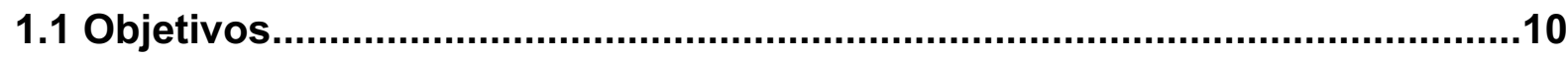

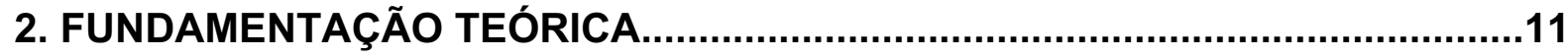

3. METOLOGIA

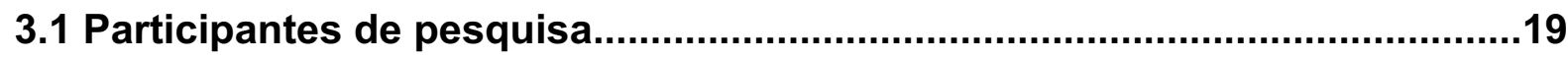

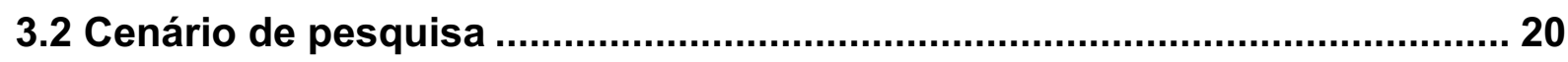

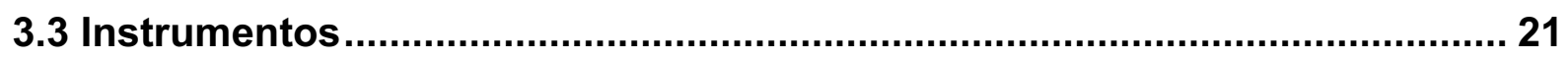

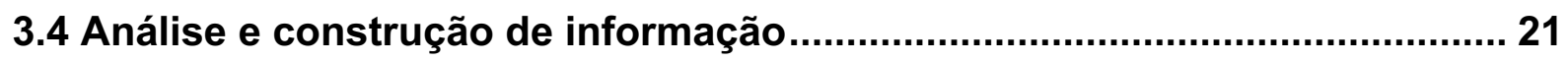

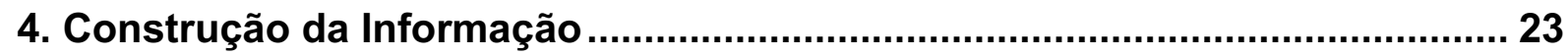

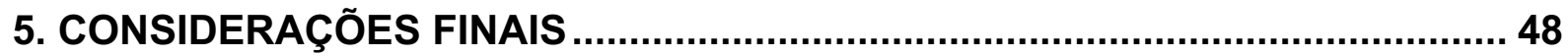




\section{LISTAS}

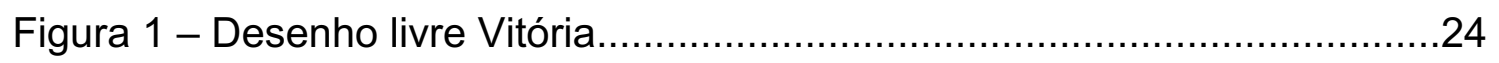

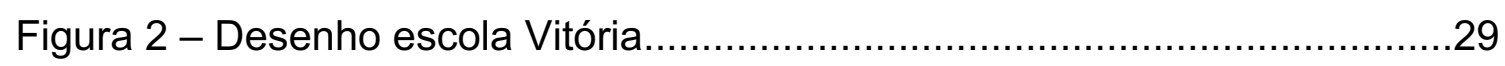

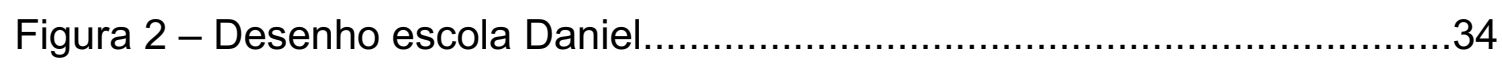

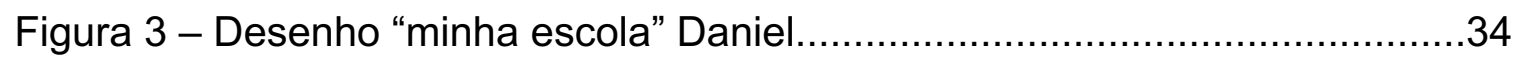

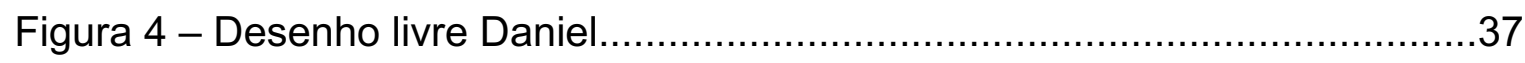




\section{INTRODUÇÃO}

Esse projeto de pesquisa aborda o tema da medicalização das crianças que tem ocorrido nos contextos de aprendizagem quando há manifestação das dificuldades do aprender diferentes do estabelecido pelo sistema educacional vigente. $O$ projeto de pesquisa assume uma perspectiva problematizadora e crítica na medida em que se preocupa com a percepção e as vivências que a criança tem quando vivencia essa situação no ambiente escolar.

A presença de crianças com dificuldade de aprendizagem, principalmente o TDAH (Transtorno de Déficit de Atenção e Hiperatividade), tem sido recorrente nos dias de hoje. Uma criança é muito facilmente diagnosticada e com isso estigmatizada, o que causa um grande impacto na sua vida, dos responsáveis e da própria escola. Os sintomas são descontextualizados e ocorre a distinção entre corpos normais e anormais, o que causa a constante busca pela normalização biológica à procura da produtividade. (MITJÁNS MARTÍNEZ, 2011). Como traz Raad (2007), há uma desresponsabilização e despersonalização causada pelo diagnóstico, em que a autonomia e o olhar individualizado para a criança saem de foco, e os profissionais atuam somente como técnicos que apenas identificam o que os exames informam.

Não se pode desconsiderar que a escola tem um papel formativo essencial na transmissão da cultura, mas será que ela tem sido tem sido capaz de proporcionar uma aprendizagem tanto no âmbito cognitivo como no âmbito de preparar as crianças para lidar com o mundo? A fragmentação dos saberes, a hierarquização do conhecimento, a classificação dos jovens a partir de resultados é uma característica do caráter universalizante e de determinação de um padrão cultural exclusivo. (CAMPOLINA, MARTINEZ; 2011). É necessário pensar em um ambiente educativo que se baseie na articulação dos significados culturais e dos sentidos subjetivos e desenvolva processos mais autônomos, contextualizados e significativos de aprendizagem (GONZÁLEZ REY, 2004).

Compreender a forma singular que a criança aprende, os significados e sentidos perpassados por essa aprendizagem, sempre relacionados com o contexto histórico e cultural da criança, é um trabalho de extrema importância, contudo ausente nas escolas. As instituições de ensino, os professores e os familiares têm 
se embasado em uma concepção médica que defende a dualidade entre saúdedoença, com enfoque biológico e orgânico, elemento de uma subjetividade social dominante que reduz o sujeito à classificação diagnóstica.

Segundo pesquisas feitas, o metilfenidato é o psicoestimulante sintético mais consumido no Brasil e o aumento de diagnósticos, bem como sua imprecisão, possivelmente é a causa do crescimento de prescrições do medicamento para o TDAH. (BRASIL, 2014). Conforme a ONU (2015a, p.42), "o metilfenidato é um estimulante do sistema nervoso central que é usado para tratar diferentes transtornos mentais, entre eles o TDAH. Seu uso excessivo tem crescido nos dias de hoje e em 2013 bateu o recorde de 71,8t nos Estados Unidos.".

Diversas pesquisas já foram realizadas acerca do tema controverso que é o TDAH. Um artigo publicado por Landskron e Sperb (2008), visa compreender como os valores e significados que vêm acompanhados ao TDAH refletem para professores. As autoras trazem a pesquisa de Davison (2009) que identificou que nos Estados Unidos o diagnóstico de TDAH tornou-se um fenômeno nacional, em que aproximadamente $40 \%$ dos alunos dentro de algumas salas de aula utilizavam psicoestimulantes, e que de 1990 até 2001 o consumo desses medicamentos aumentou cerca de $600 \%$.

O comportamento das crianças gera desconfortos nos mais diversos ambientes em que ela vive, contudo na escola é o mais evidente, uma vez que exige muita atenção e concentração. Com isso, as autoras propõem uma investigação de como é visto o comportamento das crianças com TDAH e quais são os amplos sentidos envolvidos no olhar das professoras que lidam com isso diariamente. As professoras relataram a dificuldade em relação ao comportamento hiperativo e desatento, o desempenho ruim na escola e evidenciaram a questão dos cadernos incompletos e da complexidade que era para alguns alunos a organização, focar na aula ou ficarem quietos.

Apesar de não se poder generalizar devido ao número de participantes, a pesquisa indica um entendimento patologizante das dificuldades dos alunos, sendo considerada uma deficiência. Nesse sentido, independente de causas biológicas ou psicossociais, as crianças devem se incluir num modelo pré-determinado. 
Esse estudo trouxe contribuições interessantes para nosso estudo, uma vez que deixa claro que analisar o TDAH apenas em perspectivas individuais traz uma visão reducionista e linear, pois não a abrange a multiplicidade de causas e efeitos, e a expectativa por conta do medicamento, que fará com que o alune se adapte à escola.

Um estudo realizado por Vasconcelos, Malheiros, Werner, Brito, Barbosa, Santos e Lima (2005) evidenciou a influência de fatores psicossociais no diagnóstico do TDAH. A pesquisa foi realizada com 403 crianças, de 6 a 15 anos de comunidades carentes do Rio de Janeiro, e trouxe algumas questões psicossociais mais frequentes como: brigas conjugais no passado, violência entre os pais, separação dos pais, brigas conjugais na gravidez, assassinato de um familiar, assassinato do pai e história de depressão na mãe e tabagismo materno na gravidez. Segundo os autores, esses problemas influenciam muito no fornecimento do diagnóstico de TDAH, evidenciando a importância de um olhar além do reducionismo biológico e buscar compreender os mais variados contextos que a criança vivencia.

Diante dessa problemática, pretendemos problematizar a questão do diagnóstico, das dificuldades de aprendizagem tendo em vista a criança singular, bem como a forma que o ambiente escolar acolhe essas crianças. Nesse sentido, tomando os aportes teóricos da Teoria da Subjetividade, visamos discutir a relação da subjetividade individual e da subjetividade social na composição e organização dos sentidos subjetivos de cada criança. Essa questão tem gerado debates nos diversos campos da psicologia, devido à crescente medicalização sem um acompanhamento psicológico e do anseio por um diagnóstico, além de uma necessidade de a criança se enquadrar num padrão de aprendizagem homogêneo, tornando essencial uma nova postura por parte das escolas, dos responsáveis e dos próprios psicólogos.

A partir do panorama exposto, a pesquisa realizada partiu da problematização sobre a criança com dificuldades de aprendizagem, especialmente do TDAH, voltando-se para como a criança percebe e entende o que ocorre com ela na escola. Sendo assim, foram delineados os seguintes objetivos da pesquisa: 


\subsection{Objetivos}

Objetivo Geral:

Compreender os aspectos da subjetividade individual e social de crianças com relação às dificuldades de aprendizagem e os impactos do diagnóstico para sua aprendizagem na escola.

Objetivos específicos:

$>$ Investigar as produções subjetivas das crianças que apresentam alguma dificuldade de aprendizagem atribuída pela escola ou por diagnósticos de especialistas, analisando suas interações na escola.

> Identificar os significados atribuídos pela criança à sua forma de aprender considerando os desdobramentos do diagnóstico.

> Discutir a importância dada aos diagnósticos e a medicalização na sociedade atual a partir dos processos vivenciados pelas crianças. 


\section{FUNDAMENTAÇÃO TEÓRICA}

As condições da sociedade ocidental capitalista permitiram que a medicina mercantilizasse a saúde. A medicalização é uma das ferramentas utilizadas para isso, uma vez que a partir das ideias de Illich (1975), entende-se que questões sociais são vistas como biológicas, os problemas da vida são entendidos como doenças e disfunções, estabelecendo os padrões de normalidade. Sob essa visão tudo o que foge a esses padrões é desvalorizado, provocando medo, insegurança e necessidade de conserto. Com isso surgem os rótulos, que transformam a pessoa em um objeto de estudo científico, passível de correções e medicamentos que potencializem suas capacidades (RAAD, 2011).

Essa concepção biologicista é fortalecida pelo modelo biomédico, que coloca a doença como categoria central. E com esse modelo, cria-se a metáfora mecanicista, em que o corpo passa a ser visto como uma máquina biológica com defeito. (GOULART, ALCÂNTARA; 2016).

O rótulo e a medicalização levam a uma busca maior de diagnósticos e consequentemente à estigmatização, uma vez que o sujeito passa a ser visto como um objeto de estudo da ciência. A medicina estabelece a relação entre o que alivia e o que causa sofrimento e a prática de rotular decorre de uma estrutura de dominação, em que os médicos são os encarregados de promover saúde e de organizar as necessidades dos indivíduos, estabelecendo o que é de fato prioritário. Nesse sentido "o processo de medicalização da sociedade constitui uma ferramenta de controle social" (RAAD, 2011, p.15).

Atualmente, com a facilidade de acesso à medicamentos, as experiências da vida das pessoas ficam encobertas pelo olhar psiquiátrico e sempre com tendências a serem patologizadas se forem diferentes da concepção padrão e dominante. E Como afirma Goulart (2013), citado por Goulart e Alcântara (2016, p.15), "um importante desdobramento de uma atenção pautada pela noção de psicopatologia é a retirada do potencial de mudança do campo de ação da pessoa considerada doente". Dessa forma, em vez de ser vista como um indivíduo com capacidade de agir passa a ser vista como um ser passivo e sem vontades por ser refém do seu diagnóstico. 
O TDAH (transtorno do déficit de atenção e hiperatividade) é um exemplo que se relaciona à esse processo de medicalização excessivo que ocorre em escala crescente nas sociedades ocidentais, e na maior parte das vezes, representa a biologização dos conflitos sociais, e como apontam Goulart e Alcântara (2016), não tem uma causa unicamente biológica. As diversas observações sobre os fenômenos da atualidade nos permitem dizer que com frequência a criança que dá trabalho em casa ou na escola, que não se comporta da maneira como é exigido ou que não aprende no mesmo ritmo dos demais, está mais suscetível de entrar no ciclo da medicalização. Muitas vezes os pais esquecem que precisam cuidar da criança e não do seu defeito. Passa-se o tempo e permanecem-se os rótulos: alguém conhece a criança? Do que gosta? O que deseja? Tem raiva ou medo? De que? O que pensa? Quem é essa criança? É apenas a criança fora da normalidade, que dá trabalho em casa e não aprende na escola.

O rótulo da deficiência declara a normalidade e recusa a diversidade (MITJÁNS MARTÍNEZ, 2011), e por mais que as pessoas rotuladas se empenhem, sofrem com a resistência e a descrença, sendo vistas sempre como o corpo com defeito. Uma das consequências da crescente lógica medicalizada é a iatrogênese, doença epidêmica. Segundo Raad (2007), a iatrogênese envolve uma perda na autonomia do indivíduo e do controle que ele tem da própria vida. A medicina reificada é uma nova forma de manifestação dessa doença epidêmica, pois torna o sujeito passivo diante das suas experiências.

Para Raad (2007), o diagnóstico, o rótulo e a deficiência estão associados à noção de insuficiência, partindo do olhar de que falta algo na criança. São indícios de distanciamento e impedimento da sensação de pertencer. Isso traz a questão complexa de que a sociedade não luta contra a prática de rotular, mas luta contra o que o rótulo afirma através do consumo de medicamentos.

Mitjans Martinez (2011) afirma que, no cenário educacional, três elementos se alternam: a deficiência, a exclusão e a tentativa de inclusão. O problema é que a forma como essa inclusão está sendo feita é baseada apenas em leis sem uma reflexão acerca da compreensão dos processos de saúde e doença, desresponsabilizando às demais pessoas envolvidas no cotidiano da criança, como os pais ou a escola. Dessa forma, o olhar humano é totalmente desconsiderando, de 
forma que criança seja enxergada como se ela fossea doença e não como se ela tivesse a doença

Nas escolas, as crianças com diagnóstico estudam no mesmo lugar das crianças sem ele, contudo isso apenas demonstra que elas podem dividir o mesmo espaço físico ou até de socialização, mas não necessariamente elas compartilham o mesmo espaço de completa aprendizagem. Isso evita a exclusão total da pessoa do sistema educativo, mas não faz com que a criança se sinta pertencente àquele local. Como a autora afirma:

Frequentemente, encontramos na escola crianças que são identificadas pelos seus diagnósticos, pelo que as marca como diferentes, por aquilo que lhes falta. Crianças cuja singularidade é desconsiderada em favor de um conteúdo curricular que deve ser cumprido, e que, para tanto, todos devem apresentar o mesmo ritmo de aprendizagem. (Mitjáns Martínez, 2011, p. 141).

Como corrobora Raad (2011), no contexto escolar, o diagnóstico é elaborado na noção de insuficiência, do que as crianças não têm ou deveriam ter. Com isso, quando a escola pede uma avaliação psicológica focada no diagnóstico como um rótulo há o sinal, de alguma forma, que aquela criança não está aprendendo ou se comportando da forma que deveria. Assim, a criança, muitas vezes, pode se ver e se sentir diferente, como alguém que precisa de uma atenção especializada. Os conflitos e dúvidas que podem surgir na escola acalmam-se quando a criança traz o diagnóstico, uma vez que, com isso a responsabilidade é da criança: a escola acaba não precisando estar tão comprometida com outras maneiras de ensinar. Reduz-se o problema: o aluno é o único responsável pelo seu sucesso e pelo seu fracasso.

A obtenção de um diagnóstico que justifique a dificuldade da criança tem um impacto social na sua vida. E como afirma Mitjáns Martínez (2011, p.75), "a forma como a pessoa subjetiva o defeito, em função do sistema de ações e relações que estabelece nos espaços sociais onde está inserida, e o impacto da subjetividade social que caracteriza esses espaços, constituem o sujeito que aprende". A visão dominante em relação à deficiência vem de uma trajetória de dominação e exclusão, 
bem como de uma subjetividade social em que o medo, a insegurança e a inferioridade tiveram uma função primordial.

Segundo González Rey (2005), a subjetividade é um componente constituinte das pessoas, é a organização dos processos de sentidos subjetivos gerados a partir das vivências e experiências do meio social. É um processo dinâmico, ou seja, está sempre em construção, a partir da sua interação consigo mesmo e com o outro. $\mathrm{O}$ autor destaca ainda que a constituição da subjetividade é um processo de entrelaçamento entre sujeito e meio social, ou seja, eles se interferem mutuamente. O mundo não oferece um material pronto para o indivíduo, mas esse indivíduo também constrói e possibilita novas configurações no ambiente. A subjetividade, então, se caracteriza como um sistema de configurações de sentidos que surgem e se organizam em diferentes níveis nos sujeitos e nos espaços sociais em que ele atua.

De acordo com González Rey (2005), a subjetividade social é um sistema produzido a partir das representações das vivências que os sujeitos e grupos produzem ao interagir e se relacionar com o mundo, ou seja, é a produção simbólico-emocional gerada a partir da processualidade dos sistemas humanos de ação e relacionamentos. E como traz Mitjáns Martínez (2011), a subjetividade social é a organização subjetiva dos diversos espaços sociais, produzida dentro de uma pluralidade de contextos ao longo de uma ocorrência histórica. Esta é indissociável da condição humana, e enquanto algumas pessoas se subordinam a esta subjetividade social, outras buscam possibilidades que geram tensão entre sua produção e o que é socialmente aceito.

Outro conceito fundamental da Teoria da Subjetividade, que define que todos os processos humanos se configuram de modo recíproco, é o de sentido subjetivo. Segundo González Rey e Mitjáns Martínez (2017), a articulação de elementos simbólicos e as emoções expressas nas vivências do indivíduo, no qual processos sociais e individuais se implicam de forma recíproca, são definidos como sentidos subjetivos. E a configuração subjetiva, por sua vez, é a organização de sentidos subjetivos, entendidos como a unidade entre emocional e simbólico produzido no atual instante. 
Dessa maneira, para González Rey, no sistema educacional, dar foco apenas para o sujeito individual seria uma atuação incompleta, uma vez que este está constantemente em relação com a dinâmica social.

Nesse sentido, Vygostky (2000), citado por Souza (2013, p.15), propõe a psicologia histórico-cultural, que trouxe uma nova concepção a respeito dos processos educativos. Para o autor, esses processos são resultados de uma determinada cultura e sociedade, caracterizando uma produção social.

Campolina (2014), a partir dos estudos da teoria da subjetividade, argumenta que aprendizagem é um processo essencialmente interativo e o processo do aprender está inteiramente ligado à subjetividade. Sendo assim, o social não atua como influência direta e linear no processo de aprendizagem, mas transforma a produção de sentidos subjetivos a partir das ações do sujeito que aprende. As dificuldades de aprendizagem perdem a visão apenas individual, passando a ser questionado também o próprio sistema social. Não é o defeito em si que controla o destino da criança. O defeito não tem um sentido estabelecido, ou seja, para cada um o defeito tem um sentido particular e único que não é igual aos outros.

Para González Rey (2011), a subjetividade social e suas consequências se processam a partir desse defeito, quando ligado ao diagnóstico. Este vai aparecer no meio da teia que implica as configurações subjetivas. Em vista disso, a importância de trabalhar e compreender as dificuldades e não adaptabilidades dos alunos no sistema escolar, sob o ponto de vista da subjetividade.

No sistema educativo, a construção do conhecimento, tal como se dá hoje, é baseado numa massificação e saturação de conhecimentos específicos, de forma que, segundo discutem Campolina e Martinez (2012), decreta-se um padrão sobre a maneira de pensar, de agir e de se sentir, e quem pensa, age ou sente diferente deve se enquadrar de alguma forma àquele padrão estabelecido. Desse modo, o sistema escolar determina quem está apto e quem está inapto para execução das tarefas, desencadeando assim em milhares de diagnósticos e rótulos de uma criança com dificuldade de aprendizagem. (Tunes, 2011).

A escola tem um caráter reprodutor, e um exemplo disso são as salas de aula, que trazem vários questionamentos a respeito da hierarquização, dominação e 
homogeneização. São ambientes com pessoas de idades próximas e uma correspondência progressiva de conhecimentos, habilidades e competências adquiridas no decorrer do tempo. Contudo não são ambientes homogêneos, uma vez que cada indivíduo apresenta diferenças quanto aos processos de aprendizagem, dificuldades, aptidões e ritmo, além de terem experiências e uma história de vida singular. Na sala de aula todos são alunos, e estes acabam sendo classificados quanto ao resultado (bom ou mau aluno) e quanto ao comportamento (indisciplinado, desatendo, inquieto), sem levar em consideração os aspectos sociais e individuais que estão subjacentes à produção dessa experiência. (CAMPOLINA, MARTINEZ; 2011).

Segundo a discussão de Gonzalez Rey (2006), a aprendizagem na escola está focada mais na transmissão de conhecimentos considerados verdadeiros do que pela discussão e reflexão dos conteúdos que fazem parte de um currículo. Assim, por mais que não sejam ambientes homogêneos, o processo de aprendizagem é homogeneizado, em que há apenas a verdade absoluta e a singularidade do processo torna-se secundário.

Para o autor, "O sujeito só vai desenvolver-se na tensão de sua produção singular ante a possibilidade de alimentar com sua experiência o que aprende e de alimentar o seu mundo com aquilo que aprende" (González Rey, 2006, p.32). Por isso a importância de considerar o aluno como um sujeito que aprende e de considerar que sentidos subjetivos desenvolvidos na aprendizagem são indissociáveis da complexidade da subjetividade humana.

Como questiona González Rey (2006), os professores precisam compreender que sem o interesse e vontade do aluno, a aprendizagem não deixará de ser passiva e tornar-se-á mera reprodução, além de impossibilitar a autonomia do aluno tornando-o sempre dependente de um mediador, no caso, o professor.

Segundo Pozo (2002), os professores alegam que não têm tempo de cumprir os seus programas (definidos pelo sistema), mas esgotam os alunos, que apenas observam os temas passarem tão rápido que dificilmente conseguem assimilá-los. A aprendizagem não deveria ser um processo mecânico nem estar direcionada para reproduzir e repetir saberes, e sim para interpretar, compreender e dar sentido ao conhecimento e ao mundo. 
Por outro lado, é interessante analisar o quanto a escola desempenha um papel social, psicológico e dinâmico. A educação tem um caráter de formação social e de transmitir a cultura, pois é através dela que os sujeitos percebem as relações em que estão inseridos, os signos e os significados daquela cultura em um contexto histórico específico. E a escola insere o indivíduo no convívio social, nas regras e na cultura, além de proporcionar experiências diferenciadas para os sujeitos (Campolina e Martinez, 2011).

Com isso, é necessário compreender a singularidade de cada criança, levando em consideração além do aspecto individual, o contexto e história de vida dessa criança, sem se basear na rotulação e acreditar cegamente no diagnóstico. Por isso torna-se essencial o desenvolvimento de programas que visem estimular o pensamento, a curiosidade, o interesse e um olhar singular para cada criança, respeitando os limites e o tempo do sujeito que aprende. 


\section{METODOLOGIA}

O método utilizado na pesquisa se baseia na Epistemologia Qualitativa, proposta por González Rey (2005), e evidencia a importância da reflexão, permitindo embasar e questionar os princípios metodológicos e romper com a ideia de que a pesquisa segue uma sequência de instrumentos que não produzem ideias teóricas explicativas e interpretativas. Sendo assim, é um processo construtivo-interpretativo, que vai além da relação de causa e efeito, mas se fundamenta na criação e interpretação do pesquisador.

A pesquisa qualitativa enfatiza elementos gerais da produção do conhecimento que possibilita a produção teórica "acerca da realidade plurideterminada, diferenciada, irregular, interativa e histórica, que representa a subjetividade humana" (González Rey, 1999, p. 35). O pesquisador interpreta e articula novas ideias ao seu foco de estudo, levando em consideração e como pontos essenciais para o desenvolvimento da pesquisa, as representações sociais, a história do indivíduo e seu contexto.

A epistemologia qualitativa apoia-se em três princípios (Gonzalez Rey, 1999):

Conhecimento como um processo de construção e interpretação do pesquisador que se baseia na sua produção, e não na apropriação linear de uma realidade. Ao afirmar que o conhecimento é construtivointerpretativo, rompe-se com ilusão de validade ou legitimidade de um conhecimento pela sua correspondência direta com a realidade (González, 2005). Nesse sentido, nessa pesquisa o caráter construtivointerpretativo tem como objetivo embasar como será oportunizada a expressão dos participantes visando o conhecimento explicativo sobre a realidade pesquisada.

> Legitimação do singular como fonte de conhecimento. A valorização do singular nessa proposta epistemológica retoma o lugar do sujeito como instância de estudo excepcional para entender a qualidade de qualquer processo, e escapa da padronização (Silva, 2008) possibilitando o desenvolvimento de modelos teóricos singulares no decorrer da pesquisa. Na pesquisa proposta, o caráter singular se expressa pela 
busca de compreender os impactos subjetivos do diagnóstico a partir dos casos das crianças e de suas interações sociais na escola. Tendo em conta que cada caso é único, busca-se estudar a relação entre o TDAH e os seus desdobramentos para a vida da pessoa.

> Consideração da pesquisa como um processo dialógico e de comunicação, que implica repensar o espaço social da pesquisa em sua significação para a qualidade da informação produzida (González, 2005). Anteriormente, a neutralidade do pesquisador era priorizada, contudo nesse método epistemológico a interação entre pesquisador e objeto de pesquisa é fundamental. A comunicação é um meio privilegiado de compreender as configurações e sentidos subjetivos que permitem conhecer o sujeito individual $\mathrm{e}$ as mais variadas condições que interferem nas relações do homem. (González, 2005). Considerando a comunicação como um rico caminho para conhecer as configurações e sentidos subjetivos, esse trabalho buscou um cenário social da pesquisa, com o objetivo de criar situações de interação e diálogo com as crianças, familiares e com a professora a fim de compreender os sentidos subjetivos produzidos por eles em relação ao diagnóstico, possibilitando a configuração de um espaço legítimo de produção de informações.

\subsection{PARTICIPANTES DE PESQUISA}

- Duas crianças com diagnóstico de TDAH (transtorno de déficit de atenção e hiperatividade), 1

- Um de seus familiares, totalizando dois adultos que tem contato diário com a criança.

- A professora responsável pela turma dessas crianças.

\footnotetext{
${ }^{1}$ Aspectos mais específicos dos participantes serão trazidos mais adiante na discussão dos casos.
} 


\subsection{CENÁRIO DE PESQUISA}

O cenário de pesquisa tem como objetivo criar um clima em que os participantes se sintam confortáveis e se envolvam na investigação, permitindo o acesso do pesquisador às suas reflexões e subjetividade.

Essa pesquisa foi realizada em uma escola pública de Brasília, Distrito Federal que apresenta entre seus alunos, um número alto de alunos portadores de algum diagnóstico. Esta escola foi encontrada por indicação da professoraorientadora do projeto.

Inicialmente, entramos em contato com a escola e explicamos para a coordenadora responsável o objetivo da pesquisa e a forma como esta poderia contribuir para o desenvolvimento das crianças, bem como ampliar a visão acerca do diagnóstico para se pensar em novas práticas de trabalho. Em seguida, recebemos a indicação de dois alunos que estudam no turno matutino e que possuam o diagnóstico de TDAH, sobre a dinâmica da turma e sobre a professora responsável. Inicialmente, foram realizadas observações participantes a fim de possibilitar a aproximação com os sujeitos de pesquisa e criação de vínculo com as crianças e com a professora, bem como de examinar as interações da criança, como ela age e reage, como ela brinca nesse espaço e como se posiciona com relação às atividades propostas pela escola.

Em seguida, foi marcada uma reunião com a mãe de cada uma das crianças individualmente e com a professora, que ocorreram no ambiente escolar. Em cada encontro individual, foi realizada a dinâmica conversacional e assinado o TCLE (Termo de Consentimento Livre e Esclarecido). Com a anuência da escola e dos responsáveis iniciaram-se os encontros individuais com as crianças.

Esse trabalho foi submetido ao Comitê de Ética, e todos os participantes da pesquisa preencheram o TCLE (Termo de Consentimento Livre e Esclarecido), a fim de garantir que todos estejam cientes do funcionamento da pesquisa. O número de aprovação do comitê é 1.950.388. 


\subsection{INSTRUMENTOS DA PESQUISA}

O instrumento possibilita o diálogo entre pesquisador e participante para acessar sua subjetividade e facilitar a expressão do sujeito. Como afirma González Rey (2002), os instrumentos são os procedimentos que estimulam a expressão do sujeito em pesquisa.

Nessa pesquisa, utilizamos a dinâmica conversacional e a observação participante.

\section{Dinâmica conversacional}

A conversação envolve os participantes e o pesquisador em um processo de comunicação e não segue um modelo pré-estabelecido, de forma dinâmica que possibilita o surgimento de novas ideias ao longo do percurso.

A entrevista e a dinâmica conversacional se diferem em sua natureza. A primeira se caracteriza por perguntas e respostas, em que a conversa segue um roteiro elaborado a priori. A segunda é processual, em que o pesquisador não se prende apenas às perguntas e cria uma relação de interação. A dinâmica conversacional facilita o aparecimento da expressão subjetiva do participante, e permite manifestações dos sentidos subjetivos de forma mais aberta e livre. (González Rey, 2005).

\section{Observação participante}

Segundo Martins (1996), a observação participante consiste na inserção do pesquisador no ambiente em que a pesquisa será realizada, a fim de que a convivência com o participante não seja algo estranho e possibilite a criação de condições privilegiadas para a compreensão dos processos estudados. Considerase que a participação do pesquisador na vida cotidiana pode revelar aspectos mais profundos dos processos subjetivos do sujeito.

\subsection{ANÁLISE E CONSTRUÇÃO DA INFORMAÇÃO}


Após a submissão ao comitê de ética e a aprovação para a realização da pesquisa, os procedimentos foram iniciados: primeiramente as observações participantes e posteriormente as dinâmicas conversacionais.

As dinâmicas conversacionais com a professora e com as mães tiveram a pretensão de obter informações acerca da relação deles com a criança, como é pra eles o fato da criança ter o diagnóstico e como eles lidam com isso. Para a família, as conversações trouxeram temas como o processo da aquisição do diagnóstico e as produções subjetivas acerca dele. Para a professora, as conversas abordaram como é a visão dela sobre cada criança, quais são as metodologias utilizadas para ensinar o conteúdo, como ela age dentro de sala de aula e quais são suas dificuldades em lidar com as crianças que não se enquadram no sistema escolar.

A dinâmica conversacional com a criança foi desenvolvida em encontros individuais no ambiente escolar e foram orientadas pelo diálogo na busca de entender como ela se vê no ambiente escolar, quais são suas dificuldades, como as relações que tem com a professora e com os colegas se configuram pra ela, se ela sente-se diferente por ter recebido o diagnóstico, como gosta de brincar e como ela se enquadra no sistema educacional vigente. Com a criança utilizamos a dinâmica conversacional por meio de indutores, como jogos, vídeos, brincadeiras e desenhos. Os indutores tem um papel de provocar a expressão do participante em relação à problemática da pesquisa. As dinâmicas conversacionais com a criança foram conduzidas a partir de uma linguagem mais acessível à ela.

Ao longo da pesquisa, foram construídos indicadores que, no seu conjunto, alimentam a construção da informação. Os indicadores de pesquisa são produzidos na articulaão das informações e ideias interpretativas do pesquisador que evidenciam as diferentes configurações dos diferentes processos subjetivos para cada pessoa, e nos permitem formular hipóteses sobre a questão em estudo a partir da produção teórica (Mori, 2015). Após a realização da parte empírica, foram construídos indicadores e hipóteses do modelo teórico explicativo do problema de pesquisa proposto. 


\section{CONSTRUÇÃO DA INFORMAÇÃO}

O trabalho de construção e análise da informação foi realizado ao longo do curso de pesquisa, e não visava comprovar teorias ou uma verdade única, mas compreender os aspectos subjetivos acerca do processo de aprendizagem para crianças que têm o diagnóstico de TDAH.

Esse trabalho não partiu de uma definição a priori do objeto estudado, mas teve por bases o problema a ser compreendido, e as categorias teóricas de sentido subjetivo e configuração subjetiva, uma vez que é impossível dissociar os conteúdos simbólicos e emocionais de cada caso singular da aprendizagem.

A partir da análise das informações, foram construídos indicadores que nortearam o processo de produção de hipóteses. Baseado no processo construtivointerpretativo buscou-se explorar as expressões dos participantes na sua subjetividade e processualidade, gerando ideias a partir do problema de pesquisa e dos objetivos definidos.

\subsection{O caso de Vitória}

\section{Características Gerais da participante}

Vitória tem 9 anos e está fazendo o $3^{\circ}$ ano do Ensino Fundamental pela segunda vez. Entrou na escola em 2014 e foi encaminhada para avaliação em 2015, apresentando queixa de dificuldade visual e atraso cognitivo. Contudo desde pequena frequenta médicos com regularidade, pois a partir dos 6 meses de idade teve crises epiléticas. Em 2016, recebeu o diagnóstico de TDAH e toma ritalina diariamente. Vitória mora com os pais e três irmãos e tem uma relação próxima com o pai.

Os professores apontam a dificuldade de aprendizagem de Vitória, que ainda não sabe ler nem escrever sozinha. A diretora contou que já foram feitas várias intervenções com ela e atualmente ela frequenta a sala de apoio duas vezes por semana. É uma criança que não apresenta problemas de comportamento em sala 
de aula, contudo apresenta déficits cognitivos significativos e mostra-se muito sonolenta.

Vitória estuda na sala reduzida, com 15 alunos e tem uma boa relação com os colegas. Mostra-se sempre muito prestativa e disposta para ajudar a professora, não apresentando interesse em atividades dirigidas e focadas no conteúdo curricular.

\section{Cenário social da pesquisa com Vitória}

Nosso contato com Vitória começou em 2017 por indicação da coordenação da escola por ela ter o diagnóstico de TDAH. Inicialmente ocorreram observações e conversas com ela dentro de sala de aula e posteriormente os encontros individuais. Nos primeiros dias das observações participantes, nos envolvemos nas atividades com ela a ajudando na realização das tarefas. A pesquisadora sentava ao lado dela estimulando pra que ela cumprisse as atividades a fim de criar uma relação de confiança e um bom vínculo. Interessante notar que Vitória demonstrou uma identificação significativa com a pesquisadora, o que facilitou todo o processo de comunicação, como o exemplo do desenho abaixo:

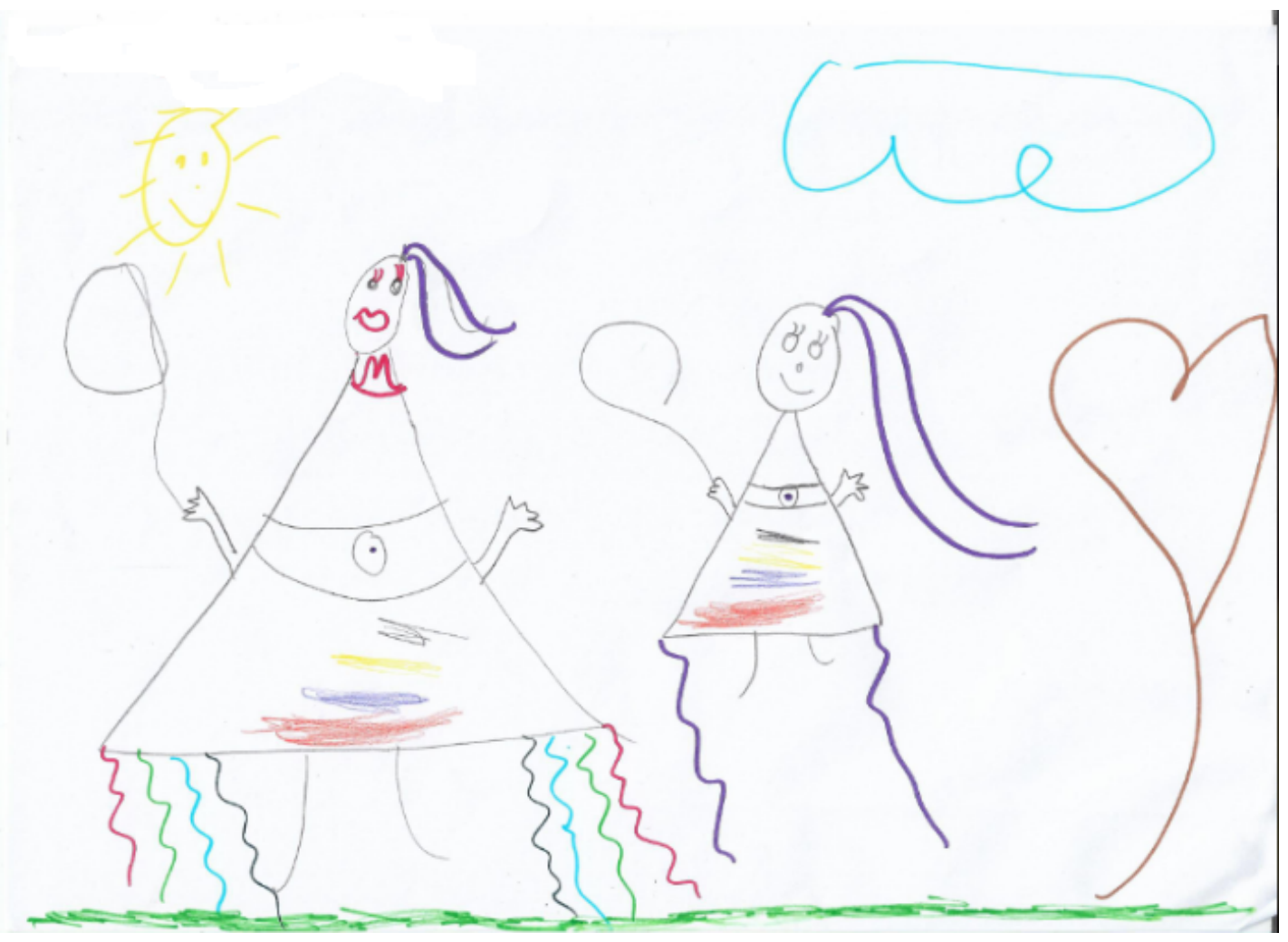

Pesquisadora: O que você desenhou?

Vitória: Essa é você e essa sou eu. 
Pesquisadora: O que é isso?

Vitória: Um balão. A gente tava passeando.

Pesquisadora: Aonde?

Vitória: (desenhou mais) A gente está ao ar livre. A gente tava voando e o balão tava puxando a gente. Ai o nosso vestido tinha uma coisa que eu desenhei aqui e ai subia e ficava toda hora pra lá e pra cá.

\section{Produções subjetivas e desenvolvimento das operações intelectuais de Vitória}

Vitória desde o início das interações mostrou-se uma criança tímida, mas muito carinhosa. No primeiro dia que fomos à escola, observamos que no recreio aparentava um pouco deslocada, mas ficou animada ao saber que nós a acompanharíamos em sala de aula.

Durante a execução das atividades escolares em sala, Vitória apresentava desinteresse e pressa para acabar logo. Um dos deveres que fizemos juntas, o comando da atividade era escrever as palavras separando por sílabas e de forma curiosa, ela só conseguia escrever a letra mais forte, por exemplo, a palavra "sofá": Vitória só escrevia o "O" e o "A". Um dos colegas sentou ao lado para ajudá-la e ela escondeu muito rápido o que estava fazendo "mandando" ele voltar para o lugar dele. Nesse momento, nos aproximamos dela:

Pesquisadora: Posso te ajudar a fazer o dever?

Vitória: Sim.

Pesquisadora: Você está com dificuldade?

Vitória: Eu sou diferente tia...

Esse momento nos chamou bastante atenção e trouxe elementos que possibilitaram a construção de um indicador de sentimentos de insegurança e de vergonha presentes em Vitória, que acompanharam todo o processo de pesquisa e que serão mais exemplificados ao longo da análise da informação. 
A irritação que o colega causou em Vitória quando veio ver o seu dever e a frase que disse "sou diferente" nos sinaliza a falta de confiança, vivenciadas com sentimentos de vergonha, que ela sente em si mesma. Como afirma González Rey e Mitjáns Martínez (2017), a criança começa a assumir pra si mesma que possui problemas de aprendizagem $e$ isso se torna um empecilho para seu desenvolvimento. Assim, o processo que ela vive na escola é de camuflar sua dificuldade, o que atrapalha o alcance de novos níveis de aprendizagem.

Na dinâmica conversacional realizada com a professora, ela traz elementos que permitem verificar como Vitória se percebe como diferente diante da aprendizagem, inclusive por usar outro livro:

"Eu colei uns adesivos em cima do número 1 do livro dela, os meninos sabem que é um livro diferente, mas eles não sabem que é um livro de $1^{\circ}$ ano, o livro dela é do $1^{\circ}$ ano. E assim, ela só faz se for com ajuda mesmo, se tiver alguém ali do lado."

Esse trecho permite compreender os sentimentos de vergonha de Vitória, pois ela percebe que os deveres que faz em sala de aula são diferentes do que os outros colegas estão fazendo, o que implica em sentidos subjetivos acerca do seu processo de aprendizagem, perpassados pela insegurança e falta de confiança em si mesma.

E essa falta de confiança reflete outro aspecto presente em Vitória que é a dificuldade de se expressar e de externalizar seus sentimentos. Em uma das atividades realizadas, "quem sou eu", a criança deveria escolher as figuras, dentre várias, que mais a representava e explicar o porquê. Vitória escolheu uma carinha triste, contudo não conseguia dizer para as pesquisadoras de forma alguma em que momentos se sentia triste. E quando tentávamos compreender melhor ela apresentava comportamentos de esquiva, mudando de assunto ou fazendo uma pergunta que não tinha a ver com a conversa.

Reparamos essa tensão e essa necessidade de fugir de assunto também durante a realização dos deveres, em que ela frequentemente levantava para beber água, olhar as horas, ir até a mesa de algum colega ou perguntar pra professora qual seria o dever de casa. E essa necessidade de fuga está associada ao sentimento de vergonha e menos-valia vivenciado por Vitória em sala, como exemplificado na fala da professora: 
"ela não tem problema de comportamento, mas tem muita dificuldade de aprendizagem. Às vezes ela dá um sorrisinho tímido, sem graça, e dá a sensação de que ela pensa: 'eu já deveria saber isso'...".

"Outro dia eles estavam escrevendo umas cartinhas, eu perguntei pra ela se ela queria um papel pra escrever também e ela disse 'não tia, eu não sei escrever'. Eu falei 'Vitória não fala assim não, você pode fazer um desenho e pode colocar algumas letrinhas que você souber', mas ainda assim ela não quis fazer.".

Esse último caso relatado pela professora reforçam e ampliam o indicador de vergonha e de tristeza vividos por Vitória e de como ela percebe essa diferença diante dos colegas.

Na dinâmica conversacional realizada com sua mãe, ela expressam esse sofrimento experenciado por Vitória:

Ela chora, todas as amiga dela sabe ler só ela que não, ai o pessoal fica enchendo o saco dela "ih, você não sabe ler" ai ela chora... chega lá em casa e chora, chora mesmo. E o pessoal fica "você não sabe ler e eu já sei" porque a turma todinha dela passou o ano passado pra 4 série, só ela que repetiu e ficou no 3 ano. Então ela fica se achando burra.

Vitória está inserida numa turma de alunos mais novos e todos sabem ler, exceto ela. Articulando esse indicador com a subjetividade social da escola na sociedade atual, que é baseada em padrões que devem ser seguidos, percebemos posturas de desistência e desmotivação. Todos os dias ela escuta frases dos colegas como "ah, isso é fácil" ou "esse dever eu já fiz", ou da família de "não sei mais o que fazer, pois essa menina não consegue aprender", ou da professora como "Vitória, te expliquei isso várias vezes", e a complexidade dos fatores envolvidos na dinâmica subjetiva de Vitória impactam na sua forma de perceber a si mesma, o mundo ao seu redor e o seu processo de aprender.

Em uma das dinâmicas conversacionais realizadas com Vitória, ela contou que seu sonho quando crescer é ser professora:

Pesquisadora: Você tem vontade de ser professora?

Vitória: Eu tenho.

Pesquisadora: Você quer ser professora de que? 
Vitória: Ah... de alunos....

Pesquisadora: Você quer ser tipo a tia Denise?

Vitória: É... não, não é igual a tia Denise. Eu quero ficar tipo assim, igual você. Ficar olhando as pessoas, ensinar a fazer o dever... até ser professora é um pouco chato.... porque tem que ficar toda hora falando com aluno, aluno não senta e me dá uma canseira ficar fazendo isso. Então melhor ficar olhando as pessoas e ajudando. Ajudar as pessoas, todos os alunos, quando precisar né...

O trecho acima citado mostra o quanto ela sente-se valorizada ao ter alguém que compreende ela além da sua dificuldade ou da sua diferença, alguém que não a julga por não conseguir fazer o que já deveria conseguir. E é interessante perceber a compreensão que ela tem acerca do que é ser professor: não é uma figura controladora e rígida, mas alguém que auxilia seus alunos em sua dimensão singular, compreendendo suas particularidades.

A diferença é representada por conceitos advindos de uma subjetividade social que frequentemente acarretam em produções subjetivas que limitam 0 indivíduo: não por suas características em si, mas pela construção social implicada. Como afirma González Rey e Mitjáns Martínez, (2017, p. 103) "toda diferença socialmente construída se expressa na produção de sentidos subjetivos que definem seu impacto no indivíduo e no seu sistema relacional". Assim, o rótulo que ela recebeu como aluna com dificuldades sérias de aprendizagem impacta na dimensão subjetiva de Vitória e na relação que estabelece com o processo do aprender.

Vitória passou a ser então uma criança desacreditada por todos, e ela traz sinais da sua solidão no processo de aprendizagem ilustrado no desenho: 


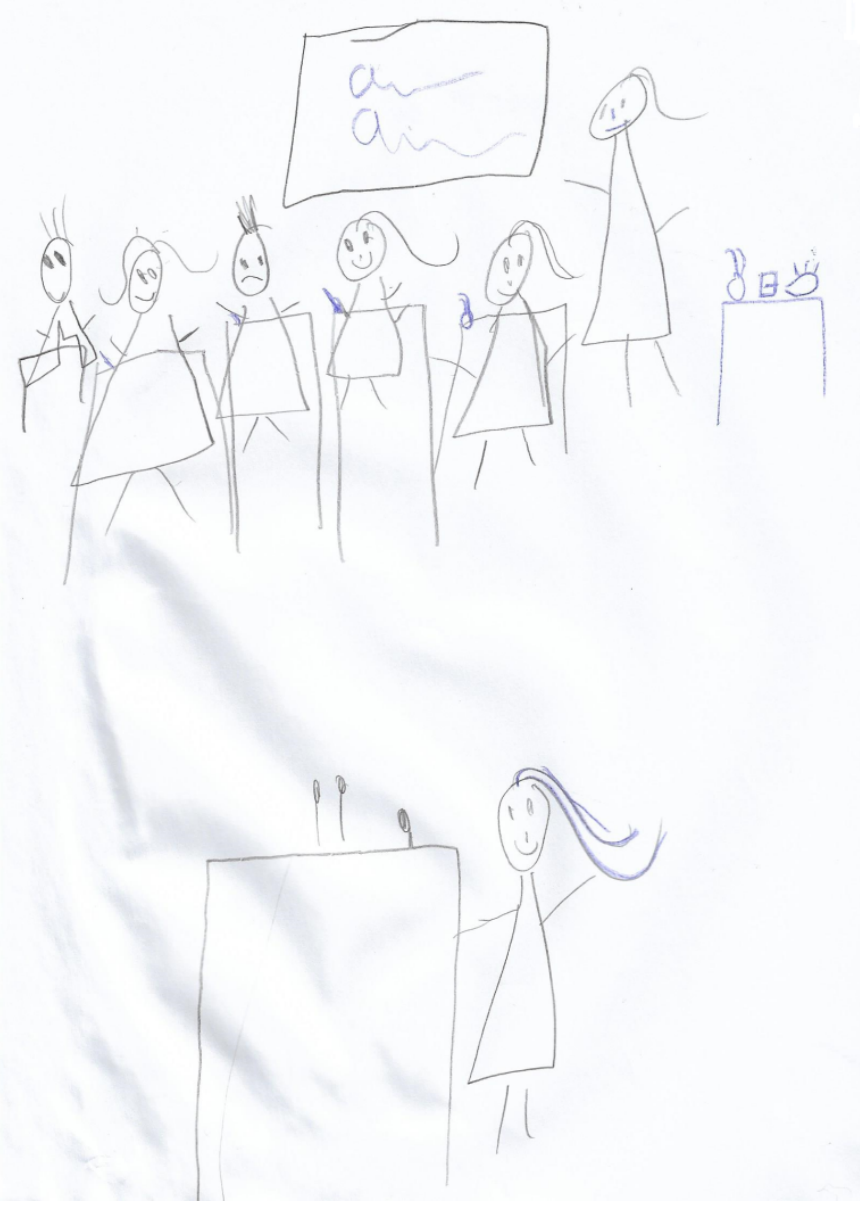

Esse desenho possibilitou a construção de indicadores acerca do seu sentimento de desamparo e abandono ao desenhar-se excluída da turma. Por mais que Vitória conte sobre a escola com empolgação e relata frequentemente que gosta muito do recreio e dos amigos, mostrando o valor da escola como significativo para socialização, ao fazer o desenho do seu dia a dia na escola, coloca-se excluída e afastada de todos. E isso expressa sentidos subjetivos do quanto ela não se sente pertencente a essa turma enquanto contexto de aprendizagem intelectual.

A professora contou o caso de um dia que uma professora da sala de recursos da escola foi auxiliar Vitória para fazer o dever:

"Ela ficou uns minutinhos com Vitória, dei um alfabeto móvel pra ver se conseguia montar algumas letrinhas, mas a professora saiu e não voltou mais 'ah ela tem muita dificuldade, eu não dou conta"'.

Esse trecho deixa claro um elemento da subjetividade social do contexto educacional vigente em que reduz a aprendizagem à aspectos operacionais, 
desconsiderado as questões emocionais, e o aluno que não consegue desempenhar essas funções é visto como um aluno com dificuldade de aprendizagem.

É curioso refletir sobre a mensagem que está sendo passada pra ela acerca da posição dos adultos em relação à sua aprendizagem, pois por mais que não fique explícita a descrença que as pessoas têm nela, ela consegue sentir essa desconfiança na forma como lidam com ela. A mãe de Vitória é empregada doméstica e sua patroa é professora, portanto faz o dever de casa com Vitória todos os dias pela tarde:

Mãe: "Ela faz o dever junto com a minha patroa. Ela me ajuda, mas você vê que ela não consegue aprender. Ela é professora, ela ensina a Vitória quase todo dia, e não entra. Minha patroa mesmo já disse pra mim: 'não sei o que fazer com ela mais'. Ela ajudou meu filho, meu filho aprendeu a ler e tem 7 anos... e Vitória tem 9... minha patroa explica e ela faz bonitinho, quando é amanhã ela não lembra mais de nadinha. Então não sei o que fazer com Vitória mais."

Ouvir diariamente de todos que não sabem mais o que fazer, que já fizeram todo o possível e que ela de fato não consegue aprender se processa para Vitória na emergência de sentidos subjetivos que constroem verdadeiras barreiras na sua aprendizagem, uma vez que ela admite sua incapacidade como atributo pessoal.

Dessa maneira, articulando os indicadores construídos acerca dos processos de aprendizagem, foi possível formular uma hipótese sobre a configuração subjetiva no processo de aprender de Vitória permeada de vergonha e insegurança. De forma indireta, as experiências dela no contexto escolar e nas suas relações, bem como a organização do seu ambiente social, construíram uma verdadeira barreira para o seu desenvolvimento e aprendizagem, experenciadas por sensações de descrença e desconfiança em si mesma e nas suas capacidades.

\subsection{0 caso de Daniel}

\section{Características Gerais do participante}

Daniel Tem 8 (oito) anos e atualmente está fazendo o $3^{\circ}$ ano do Ensino Fundamental e possui diagnóstico de TDAH há um ano. Foi encaminhado pela 
escola para avaliação por problemas de comportamento: a diretora alega que ele não permanecia quieto em sala de aula e atrapalhava os demais colegas, causando confusão frequentemente. Nesse ano, Daniel estava em um momento familiar conturbado: o pai havia sido assassinado e ocorria uma disputa judicial pela guarda da criança entre a mãe e a tia avó. Atualmente ele mora com a tia avó (a qual referencia como mãe). A escola então fez o encaminhamento para psicoterapia e avaliação com um neurologista.

Segundo a mãe de Daniel, seu primeiro ano na escola, em 2015, foi bem desgastante devido à intensa e constante agitação. Ela afirma que "ele passava mais tempo na secretaria do que na sala de aula". Com a indicação da escola para procurar ajuda, a mãe buscou mais de um neurologista e realizou uma série de exames que acusaram que Daniel tinha um grau elevado de TDAH. No final de 2016, ele iniciou o uso de ritalina.

Daniel estuda numa sala especial, de 15 alunos da faixa etária aproximadamente de 8 a 9 anos. A classe é bastante agitada, porém participativa, havendo muita disputa pela atenção da professora e da pesquisadora.

\section{Cenário social da pesquisa com Daniel}

Meus encontros com Daniel iniciaram-se em 2017, no próprio ambiente escolar, por indicação da orientadora da escola, uma vez que ele possuía o diagnóstico de TDAH. Inicialmente, realizei observações participantes em sala de aula a fim de criar o vínculo com os participantes de pesquisa e posteriormente, ocorreram os encontros individuais como facilitadores da comunicação. Segundo Bezerra (2014, p.105) "consideramos os processos de comunicação como uma via que possibilita o desenvolvimento do pensamento como um processo reflexivo, o que requer reconhecê-lo como uma produção de sentidos subjetivos".

3. Aspectos importantes das interações sociais de Daniel no contexto escolar 
O comportamento de Daniel em sala de aula nos chamou atenção, pois apresenta facilidade e agilidade na realização das tarefas cognitivas e, ainda que apresentasse desinteresse para fazer as tarefas, quando as fazia as concluía corretamente. Dentro do contexto de sala de aula, também percebemos que sua interação é complexa, pois se desentende muito facilmente com os colegas e com a própria professora, muitas vezes demonstrando agressividade ou impaciência. No trecho da informação em conversação com a pesquisadora, ele relata sua dificuldade em se relacionar com os colegas.

Daniel: Quando eu falo "para de fazer" eles já se irritam, principalmente o V. Pesquisadora: E o que eles fazem com você nessas horas que se irritam?

Daniel: (olha pra cima) é que eles ficam toda hora brigando e eu não consigo brincar de nada.

Pesquisadora: E você briga com eles também?

Daniel: Ás vezes, quando eles tão muito chatos.

Ao mesmo tempo em que vivencia conflitos com os colegas, Daniel sente necessidade de protegê-los, muitas vezes entrando em discussões que não dizem respeito a ele. Em uma conversa informal com a diretora, ela alega que Daniel tem um forte senso de justiça, toda vez que vê seus colegas em uma discussão precisa defendê-los, o que gera bastante estresse para ele.

González Rey e Mitjáns Martinez (2017) enfatizam a importância da relação nos processos de aprendizagem, uma vez que esta é social e individual. Entender a aprendizagem em sua dimensão subjetiva implica compreender o que acontece nos espaços sociorrelacionais, dentro do qual o professor e suas ações, a interação com os colegas de turma e com a própria sala de aula são subjetivados de forma singular pelo aluno. Como o exemplo no trecho citado acima, Daniel apresenta uma relação complicada e contraditória com os colegas, demonstrando em vários momentos que não se sente pertencente àquele contexto.

Em uma das observações participantes em sala de aula, ocorreu uma situação que nos chamou muita atenção para compreensão da dinâmica subjetiva de Daniel na escola. Na ocasião, a professora pediu para as crianças fazerem um desenho sobre quem elas sonhavam ser e em seguida um autorretrato. Daniel desenhou 
como sonho um lobisomem e no seu autorretrato um homem com várias espadas e metralhadoras. Contudo, a professora não achou interessante colocar esses desenhos no mural da escola para todo mundo ver, insistindo para que Daniel pensasse em outra opção para desenhar. Nesse momento, ele pegou um novo papel e fez outro desenho, contudo evidenciou insatisfação.

Posteriormente, em outro momento da pesquisa, já em conversações com Daniel, pudemos compreender o quanto essa situação o marcou, o que nos chamou mais atenção ainda para essa forma de expressão singular. Também pudemos identificar que a não aceitação da professora por um desenho fora do convencional feito por ele indicava a sensação por ele experenciada de não pertencimento à escola

Também nas dinâmicas conversacionais com a professora e conversas informais, foi possível perceber que ela apresenta uma crítica ao comportamento de Daniel e menciona como é desafiador lidar com ele, ressaltando que ele é muito insubordinado e agressivo. No seguinte trecho, foi possível perceber que a professora expressou certo incômodo nas suas interações com ele e com sua mãe, figura a qual apresenta dificuldade de lidar:

"Eu não vou pra casa tomar antidepressivo por conta disso... ta bom mãe é, é assim que a senhora quer, que não mexa nele, deixa ele dizer com essa fixação que quer ser lobisomem, com essa fixação de ficar de olhos fechados e cabeça baixa sem tomar a menor consciência do fato que aconteceu, pede desculpas na boca pra fora..."

Como afirma González Rey e Mitjáns Martínez (2017), as operações intelectuais são inseparáveis da relação constituída entre aluno e professor, e dependem da forma como o aprendiz as subjetiviza. E dessa subjetivação, participam também as experiências vividas em outros espaços e o modo como ele percebe seu lugar dentro de sala de aula. Dessa forma, fomos percebendo que o campo relacional de Daniel no contexto escolar influencia participa de forma contraditória e constitui o seu processo de aprendizagem e na produção de sentidos subjetivos acerca desse processo, como por exemplo, o vínculo que ele estabelece com a escola: com sentimentos de não pertencimento, desvalia e insegurança. 
De acordo com Mitjáns Martínez (2007) o espaço escolar e suas relações sociais são altamente significativos para o desenvolvimento das crianças, fazendo parte da constituição de sua subjetividade. Considerando esse valor do espaço escolar, é possível validar novas formas de ações para reais oportunidades de aprendizagem e desenvolvimento para o sujeito. No primeiro encontro individual com Daniel, solicitamos que ele fizesse um desenho dele na escola:

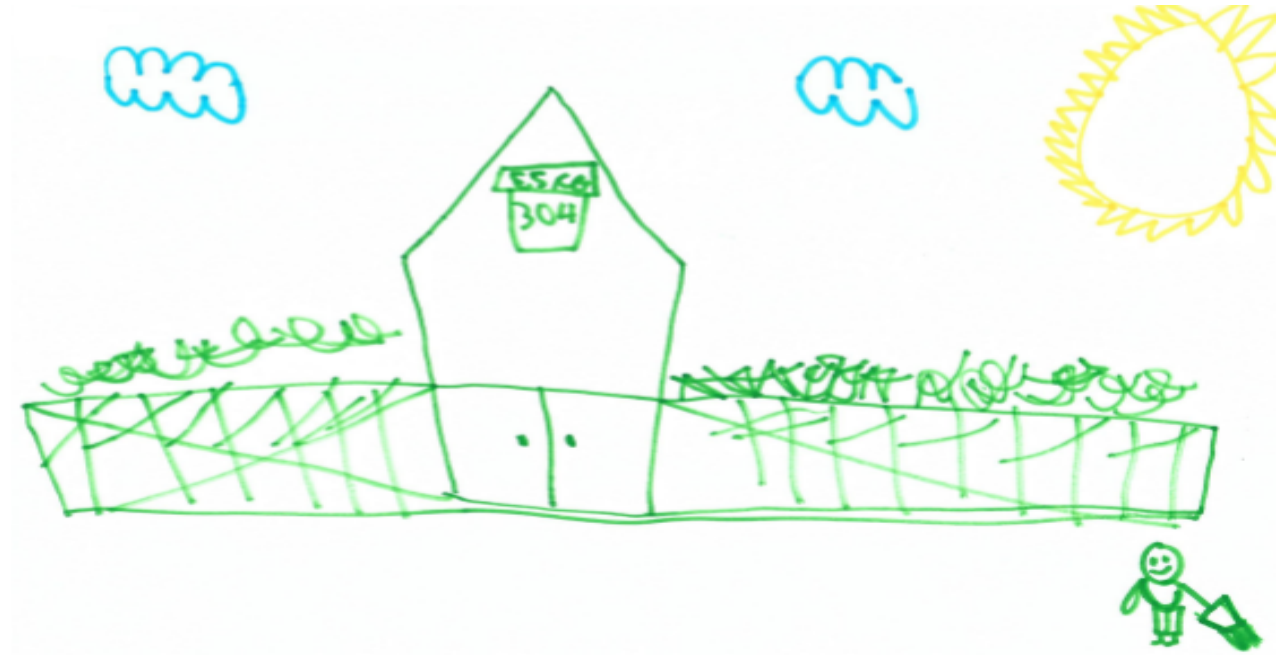

E nos chamou a atenção, pois inicialmente ele se esqueceu de se desenhar. No momento em que perguntamos onde ele estava, ele disse que estava do lado de fora. Destas observações, juntamente com as conversações, fomos construindo indicadores que Daniel não demonstrava um sentimento de pertencimento e nem parece considerar a escola como significativo para seu desenvolvimento, inclusive não evidenciando um vínculo afetivo com o ambiente escolar.

Outro exemplo de atividade que complementa essa questão foi na atividade "Minha escola", que era solicitado que ele desenhasse sua parte favorita da escola: ele não conseguia pensar na sua parte favorita e fez o seguinte desenho:

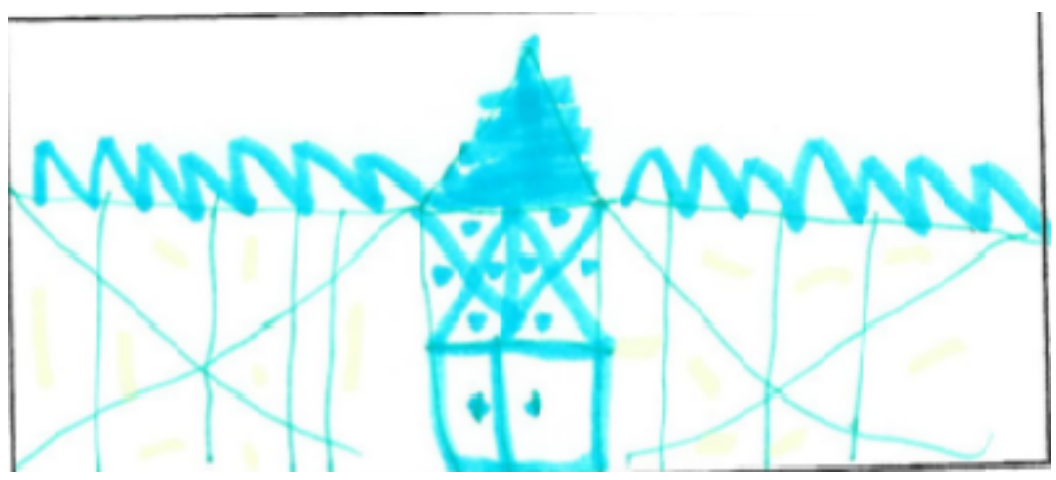


Ao analisarmos os desenhos, além de desenhar a escola bem fechada, enfatizando a porta e as grades sobre o que ele gosta de fazer na escola ou o que o motiva a vir para escola, no momento de conversação que tivemos com Daniel, depois de sua produção, a resposta foi a seguinte dele foi a seguinte:

"gosto de matemática e minha motivação é passar de ano."

Essa frase de Daniel traz elementos importantes da sua subjetividade e da forma singular como encara o ambiente escolar. Fica evidente que a escola representa uma obrigação, o que se articula com os indicadores de falta de pertencimento e de envolvimento afetivo com o contexto escolar.

O processo de pesquisa foi avançando, e ao longo dos encontros, Daniel ficou muito empolgado em mostrar as coisas que havia aprendido na aula de artes e nos vídeos de experiência que gosta de ver em casa, e nos mostrando as coisas que ele sabe fazer. Em diversas situações ele dizia "você sabe fazer tal coisa? Eu sei fazer" e fazia com muita empolgação. Enquanto fazia as atividades e desenhos, ele ia narrando tudo que estava fazendo, até as cores que ia colorir.

Essa animação ao nos mostrar coisas que ele sabia fazer foi se configurando como um indicador do quanto ele sente falta de afeto no ambiente escolar e do quanto isso interfere no tipo de vínculo que ele estabelece com a escola.

Nas análises, foi possível notar que a mãe de Daniel tem um valor significativo em sua configuração subjetiva, sendo sua amiga e companheira. E em vários momentos da dinâmica conversacional, ela demonstra que também sente-se desamparada, insegura e desprotegida diante dos acontecimentos no ambiente escolar, o que influencia nas construções subjetivas de Daniel acerca do indicador acima citado:

"eu tô tão cansada, minha mãe tá tão cansada... Tem hora que eu falo assim que "meu filho vou tirar você da escola, vou botar você em outra escola porque você tava indo tão bem, e agora...."

"me machuca porque eu vejo que ele tá sofrendo e eu não sei como ajudar ele" 
Os sentidos subjetivos relacionados ao sentimento de rejeição vivenciado na escola podem ter levado Daniel a agir na defensiva com os colegas, de forma agressiva rejeitando assim a construção de vínculos afetivos e emocionais. Nesse sentido, "Estamos diante de um conjunto estável e autogerador de emoções e processos simbólicos que se expressam na configuração subjetiva da personalidade da criança". (Bezerra, 2014, p.108).

\section{As produções subjetivas de Daniel no processo de aprendizagem}

Compreender a aprendizagem como uma configuração subjetiva exige uma investigação profunda nos vários espaços de vida da criança envolvidos na sua produção intelectual ou comportamental em sala de aula. No caso de Daniel, foi importante entender a aprendizagem que estava configurada subjetivamente por ele por detrás de seu comportamento agressivo, agitado e inquieto, levando-o a um tipo de produção simbólico-emocional que impedia o avanço dos seus relacionamentos sociais.

Durante os encontros individuais com Daniel, comumente, em desenhos e brincadeiras, utilizou representações de monstros, tubarões e criaturas sobrenaturais. Por meio dessas atividades lúdicas, bem como a partir das conversações com ele sobre seus desenhos, consegui ter acesso à expressão subjetiva dele e entender que sua dinâmica subjetiva direciona para um tipo de produção subjetiva apontado para a insegurança em relação a seus vínculos afetivos e necessidade de proteção.

A partir das conversações e análises dos desenhos, podemos elaborar um indicador sobre a necessidade de segurança e de proteção de Daniel. Devido ao histórico familiar, essa carência de sentir-se protegido foi sendo construída e faz parte de sua história de vida. A partir da conversação sobre um dos desenhos feitos, ele relata suas experiências. 


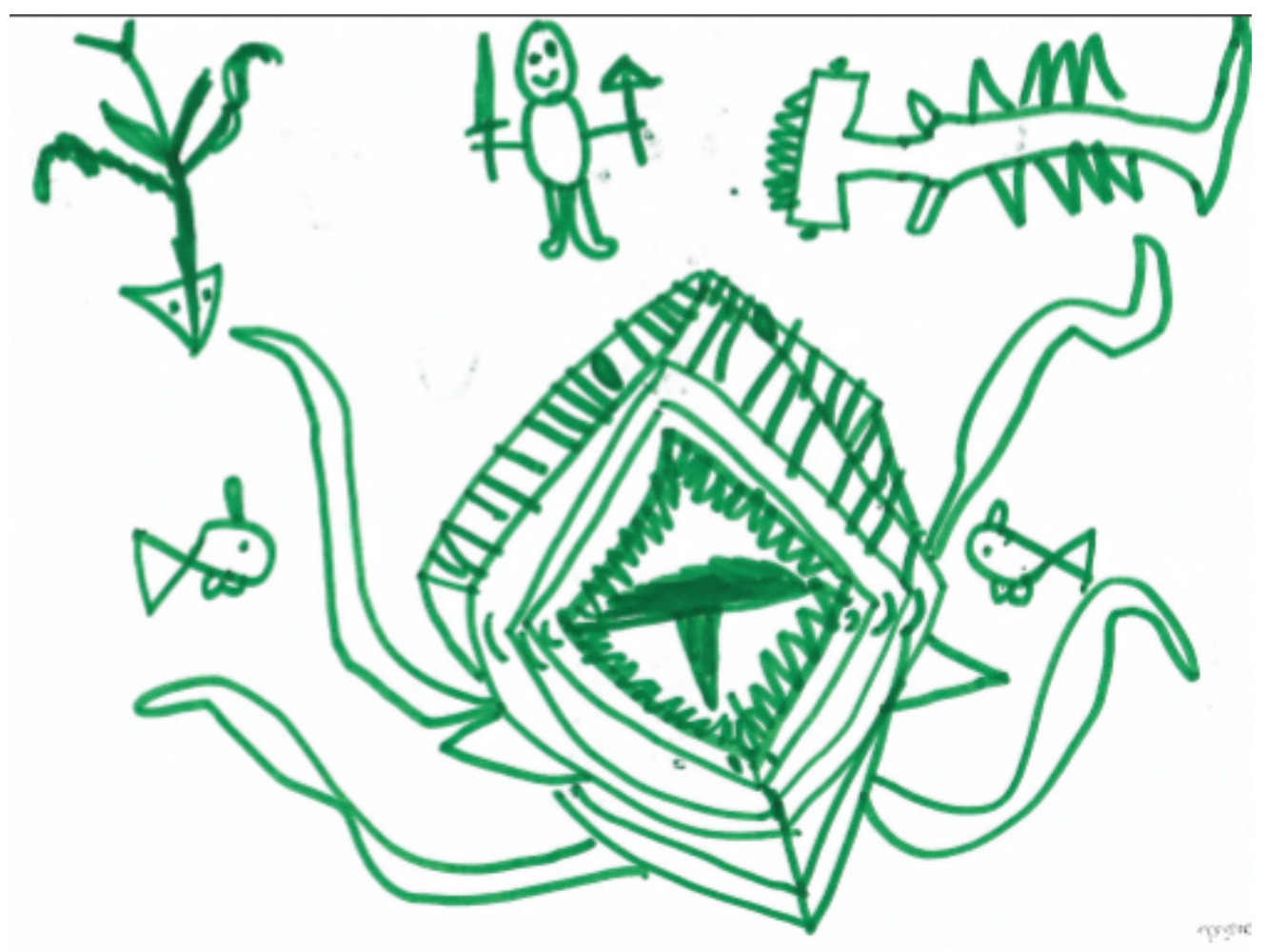

O trecho abaixo é rico de imagens e emoções:

Pesquisador: O que você desenhou?

Daniel: Um tubarão polvo de um filme que eu assisti. Eu não me lembro o nome, mas era de um tubarão polvo que vira um mutante do exército.

Pesquisador: Que tipo de filme você gosta de assistir?

Daniel: De tubarão.

Pesquisador: O que mais tem no seu desenho?

Daniel: Uns peixes, mais um tubarão mutante e uma lula peixe.

Pesquisador: E esse quem é?

Daniel: Sou eu.

Pesquisador: E o que que tem na sua mão?

Daniel: Uma espada e uma lança

Pesquisador: E o que você vai fazer com essa espada e com essa lança?

Daniel: Tentar matar ele.

Pesquisador: Você vai tentar matar o tubarão polvo? Porque? 
Daniel: Porque ele tava tentando matar todo mundo, podendo fazer mal pra cidade.

Pesquisador: E você vai defender?

Daniel: Aham

Pesquisador: E porque você quer defender a cidade?

Daniel: Pra ele poder não atacar mais e não matar ninguém ué.

Nesse diálogo, procurei não julgar seus desenhos, o que percebi que facilitou sua expressão imaginativa, aspecto fundamental da subjetividade da criança. Em alguns momentos de conversação, Daniel demonstra o quanto é bom ele ter um contexto relacional para poder desenhar seus monstros e bichos diferentes sem julgamento ou repressão, forma como muitas vezes sente-se no ambiente escolar, corroborado pelo trecho a seguir da mãe:

"ele já botou na mente dele que o que acontece quando ele fala as pessoas não dão importância... Então a gente sente que ele não se sente protegido".

Foram construídos elementos do indicador de necessidade de segurança de Daniel em vários outros momentos e atividades realizadas, como quando estava contando que o que gosta de fazer nos momentos livres é assistir vídeos de sobrevivência:

Daniel: Sabe qual o único jeito de você fugir de um tubarão? É dar um soco na guelra dele e fugir o mais rápido que você pode.

Pesquisadora: Como você sabe disso?

Daniel: Ah, num vídeo sobre sobrevivência. Se você tá em situações perigosas... tipo, você pulou de paraquedas e o paraquedas não funcionou... não não, pulou de um avião e o paraquedas não funcionou, você tira o paraquedas que não tá funcionando e usa o reserva.

Pesquisadora: E você gosta de assistir esses vídeos de sobrevivência?

Daniel: Gosto.

Em outro momento, um processo subjetivo semelhante emerge, como no desenho da escola com vários arames farpados e grades: 
Daniel: Pra poder proteger ué.

Um fator que está muito presente na história de vida de Danieli e que se estende para o campo da aprendizagem é o valor do pai, que morreu há alguns anos. Em uma das atividades, ele fez sua carteira de identidade com o intuito de propiciar um momento de reflexão e produção de sentidos. E assim, ele escreveu que a palavra que o melhor representa é "pai". Na segunda atividade quando assistimos ao vídeo "um menino, um vídeo-game, um presente e um cachorro com deficiência", um curta que leva à reflexão acerca da perfeição e da diferença, ele conta que o pai dele era diferente, que ele tinha 2,10 e mal passava pela porta de casa, contando com muita animação.

O trecho abaixo da conversação com a mãe tem uma carga emocional forte, possibilitando compreender a carência de Daniel e a importância do pai na sua dinâmica subjetiva acerca dos processos de aprendizagem que está relacionada com a dificuldade que tem de se organizar com a ausência desse pai.

"Quer dizer que tudo tem assim, é uma historia assim muito dolorida. (choro) Ele não sabe de toda a historia, sabe de pedaços pequenos, eu acho assim que não é até legal falar porque ele sofre tanto com a ausência do pai..."

“Ele já me disse: Ah se Deus levar a senhora eu vou pedir pra me levar junto. Ou então ás vezes, eu já peguei ele orando. Uma vez ele falou assim, "Deus, você levou meu pai, porque que o senhor não levou logo eu e minha mãe junto?"E eu perguntei: Porque que você orou? Ele disse: "Ah, pra que que eu vou ficar aqui sem meu pai e sem a senhora, então que levasse e ficasse nós 3 la em cima".

Muitas vezes Daniel se mostra agitado e agressivo, contudo também mostra através dos desenhos e do que gosta de fazer, sua fragilidade e sua necessidade de se sentir protegido contra os monstros que o aterrorizam. E evidencia que os sentidos subjetivos acerca do aprender ou se comportar na escola estão configurados fortemente aos aspectos históricos e culturais da vida dele, bem como dos sentidos produzidos em diferentes espaços de sua experiência, tornando assim um problema a redução ao diagnóstico.

Dessa maneira, os aspectos da subjetividade individual da criança passam a ser categorizados como sintomas ou dificuldades causados por um transtorno, 
tornando-se uma barreira que impede o processo de inclusão escolar (González Rey e Mitjáns Martínez, 2017). E a redução ao diagnóstico constitui um alívio para a escola e para a família num processo de desresponsabilização, em que elementos históricos da vida do sujeito são desconsiderados, uma vez que sua dificuldade tem um nome e uma causa externa ao indivíduo.

A necessidade de atenção de Daniel se disfarça em uma postura defensiva e provocativa que o dificulta seu envolvimento afetivo com a professora, com os demais colegas de sala e com o próprio ambiente escolar. No discurso da professora, fica claro o quanto ele é uma criança que demanda atenção e que precisa ser notado, mas muitas vezes ela mesma não consegue suprir essa carência, como no trecho a seguir:

"ele me mostrou uma carência extrema. Eu tenho todo um respeito pela história de vida dele, agora, não pode me botar nas costas a responsabilidade de suprir essa carência, de dar tão mais atenção assim pra ele, a ponto de praticamente adivinhar os pensamentos dele... Mas ele tem dificuldade de se colocar e de se perceber e você tem que ir la resolver. Foge da minha capacidade de adivinhar o que ele ta pensando"

Essa dificuldade citada pela professora de se perceber e de se posicionar é expressa em várias atividades que exigia que ele tivesse uma autorreflexão, como nas atividades que foram elaboradas para ele como a da carteira de identidade, minha escola e eu sou assim. Quando a tarefa exigia que ele parasse para refletir sobre quem ele era, sobre o que ele gostava, sobre o que ele não gostava ou sobre outros aspectos de sua vida pessoal ele respondia "não sei".

Por exemplo, utilizamos com ele o vídeo chamado "escolhas da vida", que fala sobre os papeis sociais que, na nossa sociedade, cabem aos adultos e às crianças, nos valores de vida passados para elas em um contexto de educação baseado na padronização e na censura da criatividade e como essas atitudes refletem no modo como as crianças percebem os seu papel social. Na conversa após o vídeo:

Pesquisadora: O que você achou desse vídeo?

Daniel: Legal.

Pesquisadora: E você acha que ele é parecido com a nossa realidade? 
Daniel: Ah sei lá...

Pesquisadora: Você acha que na escola as crianças vão ficando mais cinzas?

Daniel: Acho que sim. As vezes..

Pesquisadora: E que vezes?

Daniel: Sei lá. Não sei...

Ao longo dos processos de conversação, pudemos perceber que, aos poucos, Daniel apresentava mais facilidade de se abrir e de expor sua opinião, pois estimular a reflexão sobre quem ele era, sobre os acontecimentos da escola e sobre suas relações permitiu enxergá-lo como pessoa singular que é e assim valorizá-lo. Dessa forma, sentiu-se à vontade, possibilitando a emergência de sentidos subjetivos que apareceram na nossa relação.

Em uma das visitas à escola ocorreu um episódio que me chamou bastante a atenção: Daniel passou mal durante a sala de aula, vomitando, e nós intervimos: perguntamos o que ele tinha e se queria ligar para a mãe e ele teve dificuldade de explicar o que estava acontecendo ou o que gostaria de fazer. Apenas disse que passava mal e que sentia o corpo ficando quente. Então buscamos questionar em que momentos ele se sentia assim ou onde eram as dores, mas ele não conseguia palavras para explicar. Após ligar para a mãe vir buscá-lo, sentamos junto ao portão enquanto a esperávamos. Ele coçou o olho com lágrimas e só conseguia dizer "estou cansado". Perguntamos porque ele estava cansado e a resposta foi: "ontem eu andei muito". Depois de um tempo esperando Ihe dissemos que teria que voltar para sala e ele falou que queria voltar. Alguns minutos depois a diretora veio chamálo, pois sua mãe tinha chegado. Ao sair da sala, Daniel disse "tchau" uma vez e não obteve resposta de nenhum colega ou da professora. Repetiu "tchau" mais duas vezes, na terceira falando bem alto e bravo.

Esse episódio permitiu que alguns indicadores fossem reforçados:

1) a dificuldade de Daniel de se expressar, ao não conseguir se perceber, perceber suas dores e sintomas e nem quando eles ocorrem (uma vez que a diretora disse que ele tem tido esse tipo de problema com frequência).

2) O quanto a escola não the oferece segurança, o que reflete nos sentidos subjetivos produzidos acerca do ambiente escolar: no momento em que 
Daniel passou mal, a dinâmica da aula seguiu normalmente, sem ninguém perguntar o que ele precisava naquele momento. Como pesquisadoras, sentimos a liberdade de intervir e levá-lo para fora de sala de aula. E no segundo momento, após voltar para a sala e se despedir das pessoas não obter resposta, o que o deixou bastante chateado, reforçando o sentimento de não pertencimento de Daniel em relação à escola.

\section{B. Reflexões sobre a Ênfase no diagnóstico e medicalização na sociedade atual - articulando os indicadores dos casos de Daniel e Vitória}

Segundo González Rey e Mitjáns Martínez (2017), cada escola tem uma subjetividade social singular, na qual podemos identificar as formas dominantes da subjetividade social da sociedade. E por uma construção histórica do entendimento sobre deficiência, por ser considerada um desvio do desenvolvimento normal, vemos hoje uma concepção descritiva e reducionista desta, assim como das dificuldades de aprendizagem. O foco está no defeito, não no sujeito ou nas suas implicações em termos educacionais. Concordamos com a visão de Mitjáns Martínez (2007) "o defeito é um elemento que participa da constituição subjetiva do sujeito que o possui".

Assim, por mais que a patologização das dificuldades escolares seja algo generalizado na nossa sociedade, podemos perceber que cada instituição escolar apresenta uma forma específica de enxergar e lidar com elas. A escola onde a pesquisa foi realizada é considerada uma escola inclusiva, no sentido de aceitar muitos alunos com diagnóstico. Contudo, pudemos observar com frequência expressões como "tenho dois TDAHs nessa turma" ou "essa atividade é desenvolvida para os meus downs". São frases que denotam elementos de uma subjetividade social construída com foco no problema e baseadas numa visão homogênea da deficiência, que se estende para a configuração de práticas e modos de pensar e sentir na escola.

Como afirma González Rey e Mitjáns Martínez (2017, p.109) “O diagnóstico, ao ser concebido como um elemento verídico que tem o poder de explicar certas dificuldades dos indivíduos, constitui parte importante da subjetividade social 
dominante". Nesse sentido, a ênfase no diagnóstico constitui uma forma de "alívio" para o professor, para a família e para a escola no sentido de eximi-los da responsabilidade desses processos (GONZÁLEZ REY, MITJÁNS MARTÍNEZ; 2017). No discurso da professora, ao falar sobre lidar com demandas diferentes, podemos concluir que o diagnóstico não é essencial para entender o básico: que as crianças são heterogêneas e demandam atenções diferentes, têm dúvidas diferentes, têm dificuldades diferentes e enquadrá-las em um único sistema de aprendizagem não facilita o trabalho do professor e nem a aquisição da aprendizagem das crianças. Como afirma a professora:

"fulano é apenas letrado, mas não alfabetizado, o outro é letrado mas independente, o outro já precisa mais de ajuda; a outra não sabe ler ou diferencias os sons do alfabeto, o outro não consegue fazer a atividade sem ajuda..."

A proposta de inclusão é garantir o acesso contínuo da vida em sociedade, que deve ser guiada para a aceitação das diferenças e da diversidade humana. Assim, cria-se uma visão restrita de inclusão, compreendida como a incorporação de alunos com necessidades especiais nas escolas regulares, ou seja, a partir do diagnóstico, são "adicionadas" estratégias de apoio à aprendizagem da criança. (MITJÁNS MARTÍNEZ, 2015).

Na escola vive-se um paradoxo entre o discurso de "somos todos diferentes e devemos respeitar essa diferença" e a prática ao manter um sistema padronizado para uma turma, desconsiderando tantas singularidades e posições diferentes no processo do aprender.

Um exemplo desse paradoxo é Vitória: ela é enquadrada em uma turma de $3^{\circ}$ ano pela segunda vez e suas particularidades do processo de aprendizagem são vistas como atraso ou incapacidade, potencializando com frequência as descrenças que são depositadas nela. Exemplos como o de Vitória são comuns nos dias atuais, e de certa forma tencionam a subjetividade social, que é caracterizada pela eleição de um padrão dominante.

Durante a dinâmica conversacional, questionei a visão da professora sobre lecionar para uma turma reduzida: 
"Se a gente for analisar friamente em termos numéricos, é maravilhoso porque eu tenho menos relatórios pra escrever, se eu for fazer lembrancinha eu tenho menos lembrancinha pra confeccionar, eu tenho 15 cadernos pra olhar, eu tenho 15 pais pra atender. Então em termos numéricos é isso. Agora, o que não significa que 15 eu tenho menos trabalho. Porque se fosse assim, quem tem filho único, o filho seria garantido em sucesso. E me perguntam "você tem só 15 alunos e mesmo assim você vai reprovar 3? Como você não deu conta dos seus 15? "Mas não é porque eu só tenho 15 , que os meus 15 tem que ser um sucesso.".

Esse trecho ilustra um aspecto importante da subjetividade social da escola acerca do sucesso escolar, caracterizado por este discurso que é orientado essencialmente para elementos cognitivos e intelectuais, desconsiderando o aluno como sujeito da sua aprendizagem bem como, vários aspectos simbólicos e emocionais que envolvem a aprendizagem.

Assim, em grande parte dos casos, caracteriza-se aprendizagem como tendo um sentido único, baseado na mera assimilação de conteúdos e alunos que não apresentam dificuldade de memorização ou reprodução de conteúdos passam desapercebidos como crianças que podem demandar uma certa atenção. É o caso de Daniel, que não apresenta problemas cognitivos e, na visão da escola, não apresenta problemas na aprendizagem. Como na frase da mãe de Daniel na dinâmica conversacional:

"É complicado... nunca tive isso na família então assim, a gente ta aprendendo, não ta sendo fácil... A gente pega uns cavalo que vem conversar com a gente... Porque se a escola ta dizendo que ta tudo bem...".

No trecho acima, a mãe estava relatando um episódio de que o pai de um dos colegas de turma a procurou para reclamar do comportamento de Daniel no recreio e o fez de forma agressiva na frente da criança. Quando a mãe procura a escola para saber como está o desenvolvimento de Daniel, esta afirma de que ele está indo muito bem. Elemento de uma subjetividade social que reduz a aprendizagem ao aspecto cognitivo.

Dessa forma, a consideração de apenas um tipo de aprendizagem, de caráter reprodutivo e pouco reflexivo, coloca em segundo planos os aspectos subjetivos inerentes ao processo de aprender. O valor da aprendizagem não é investigado, 
uma vez que Daniel consegue boas notas, assim como intensificam os sentimentos de vergonha, menos-valia e incapacidade de Vitória.

Da mesma forma, no caso de Vitória, não se questiona mais o significado que a aprendizagem tem para ela, qual a representação elaborada, por ela, desse processo. Apenas é vista como uma aluna destinada à evasão escolar, pois já "fizeram de tudo" para ela aprender e ainda assim, ela não aprende. Como na frase da professora:

"E eu fico preocupada, o que vai ser dessa menina, porque ela já está ficando mocinha... E vai ser uma repetência atrás da outra? Sabe, eu fico pensando o que vai ser? Uma candidata à evasão, a abandonar escola?"

A visão educativa vigente que acredita que o sucesso do aluno depende unilateralmente da relação professor-aluno, da qualidade do docente e da capacidade dos estudantes descontextualiza os aspectos subjetivos tanto do professor, quanto do aluno nos vários espaços sociais (GONZÁLEZ REY, MITJÁNS MARTÍNEZ; 2017). Assim, baseado na visão de que as ações humanas são baseadas em processos simbólicos e de relação e de que o sucesso escolar não é linear com o papel do professor, o trecho a seguir da dinâmica conversacional da professora nos possibilita compreender um pouco dos aspectos subjetivos dela que influenciam nas ações que tem em sala de aula com os alunos:

"Então é uma profissão muito, muito cansativa pra mim. Uma profissão que eu imagino que a gente tem mais chefes, eu sempre falo, quem tem mais chefe é o professor: porque todos os pais dos meus alunos eu sinto como se fossem meus chefes, eu tenho a direção da escola e eu tenho os pais dos meus alunos. Eu me sinto assim que eu preciso prestar os meus serviços, que todos são meus chefes e todos esperam o melhor de mim."

Esse fragmento da conversação traz elementos que nos remete a ideia do quanto muitas vezes a professora sente-se pressionada e o quanto essa sensação de desgaste e cansaço interfere na relação e no vínculo que estabelece com os alunos. Assim, a forma como a professora vivencia subjetivamente essa pressão, perpassada pela noção de sucesso na sociedade atual, é válida e legítima, uma vez que é de responsabilidade do professor que o aluno aprenda e tenha boas notas, desconsiderando os aspectos subjetivos dele que emergem na relação com seus alunos. 
Muitas vezes a dificuldade de aprendizagem é tida como uma verdade absoluta apoiada em diagnósticos, como um fato naturalizado, sem nenhuma articulação com as demais configurações subjetivas e história de vida da criança. Como é o caso de Vitória, que carrega o diagnóstico de TDAH e ninguém questiona esse rótulo, afinal de contas ela apresenta déficit na aquisição de conteúdos. A mãe dela conta:

"Ele toma a ritalina, só que ela quando ela toma ela dorme muito, ela não tem fome... ela não come ai eu fico preocupada. Eu pensei até em falar com a médica pra tirar, não ta adiantando, tem 2 anos que ela toma e não ta resolvendo não, não ta fazendo nada."

Contudo, como em sala de aula apresenta muita dificuldade de ler ou de escrever e, para ter alguma alteração curricular, precisa de um laudo atestando seu defeito, sua dificuldade se concretiza em uma categoria: o transtorno de atenção e hiperatividade, desconsiderando os processos simbólicos e emocionais que se expressam nessa experiência vivenciada diariamente por ela.

A professora, em uma conversa informal, relatou uma estratégia muito interessante utilizada por ela: ela alega que sentia Vitória muito desanimada e sem motivação para a realização das tarefas, então a professora inventou uma história. Vitória gosta muito da cantora Anitta, então a professora, de forma lúdica:

"Sabe a Anitta? Então, ela precisa escrever as letras dela para cantar, então ela também foi à escola aprender a ler e a escrever para fazer suas músicas."

A partir desse dia, a professora contou que Vitória sentiu-se animada para fazer as atividades propostas. Essa atitude da professora evidencia o quanto ler e escrever estavam carregados de sentidos subjetivos associados ao fracasso e desconfiança em si mesma, e que dar um significado para essa aprendizagem na ação de aprender, que está relacionado com aspectos singulares de Vitória, fez com que ela se sentisse interessada e capaz de desempenhar as tarefas.

Baseando-se nos critérios diagnósticos utilizados para descrever o Transtorno de Déficit de Atenção e Hiperatividade, facilmente Vitória é enquadrada nessa classificação, principalmente pela desatenção. Contudo, ao partirmos de uma análise descritiva, acabamos reduzindo o sujeito condenando-o à patologização, 
cristalizando as possibilidades de compreensão subjetiva e singular envolvidas no processo de aprendizagem. (BEZERRA, 2014).

Dessa maneira, questões individuais da história de vida de Vitória como, por exemplo, as crises epiléticas e os anos de ingestão de medicamentos, são desconsiderados como aspectos que podem dificultar a aprendizagem de Vitória. Assim como aspectos da história de vida de Daniel, permeados por violência, sofrimento e sentimentos de abandono, são totalmente esquecidos ao se fechar o diagnóstico de criança hiperativa, sendo levado em conta apenas um aspecto descritivo para justificar a dificuldade de apender. 


\section{CONSIDERAÇÕES FINAIS}

A partir da problematização proposta pela pesquisa, pode-se reconhecer a relevância de refletir sobre os processos subjetivos no processo de aprendizagem de crianças com diagnóstico de TDAH. Compreendê-los em sua dimensão complexa e singular possibilita o acesso a aspectos específicos da configuração humana que só podem ser entendidos ao se considerar elementos históricos, sociais, culturais e individuais. Assim, a partir da Teoria da Subjetividade e sua perspectiva históricocultural, que embasam esse trabalho, é possível compreender que processos subjetivos associados à história de vida da criança, bem como a organização do seu meio social, são inseparáveis do aprender, do posicionamento do aluno e do significado dado por ele à aprendizagem.

Os desdobramentos desse estudo direcionam a discussão para a compreensão da aprendizagem como um processo complexo que implica na capacidade do aluno de aprender operacionalmente e de forma reflexiva, gerando sentidos subjetivos que lhe permitam posicionar-se diante das diversas situações que Ihe são apresentadas. Assim, compreender a aprendizagem sob a perspectiva da subjetividade permite uma representação de produções simbólico-emocionais que integram a vida individual e social do sujeito, considerando tanto os processos operativos do pensamento quanto a sua dimensão subjetiva.

A partir das análises da informação e construções de indicadores elaborados no decorrer da pesquisa, podemos refletir de forma conclusiva sobre os seguintes aspectos:

1) Compreender a aprendizagem sob a perspectiva da subjetividade permite uma nova concepção acerca das dificuldades escolares saindo da lógica reducionista e patologizante para uma visão singular de um sujeito com potencialidades. Dessa maneira, possibilita a compreensão da configuração subjetiva de cada participante envolvido na pesquisa com as diferentes formas de aprender, rompendo com a dicotomização entre o cognitivo e o afetivo no processo de aprendizagem.

2) A história de vida do sujeito toma forma nos modos como ele se relaciona com a aprendizagem, de forma dialógica e que vai além do aspecto cognitivo operacional. Assim, as dificuldades de aprendizagem não se reduzem à um 
transtorno, como no caso dessa pesquisa, ao TDAH, mas se relacionam com o contexto e história individual que essa criança traz.

3) A patologização pode produzir sentidos subjetivos acerca da relação que o aluno estabelece com a aprendizagem que mais dificultam seu desenvolvimento do que o favorece. Assim, o rompimento com a visão biomédica e com a ideia de medicalização, que foi problematizada nesse trabalho, é essencialmente a de considerar a criança como uma pessoa ativo do seu processo de aprender, não a diminuindo ao diagnóstico.

4) A aprendizagem escolar é uma teia relacional entre a subjetividade individual e a subjetividade social da instituição escolar. Assim, as relações com os professores e as concepções deles acerca da aprendizagem e da sua dificuldade interferem na emergência de sentidos dos alunos sobre seu processo. Nos casos apresentados, aspectos da subjetividade social da escola e aspectos subjetivos da professora e interferem na relação que ela estabelece com os alunos e, consequentemente, no tipo de relação que os alunos dão à escola e à aprendizagem.

Portanto, partindo do objetivo dessa pesquisa de compreender os aspectos subjetivos de crianças com relação às dificuldades de aprendizagem, podemos perceber que as crianças receberam um diagnóstico que irá acompanhá-los ao longo de sua vida: o rótulo permanece sem considerar a existência de questões subjetivas que não cabem dentro desse rótulo e muito menos são explicadas por ele. A forma como ambos subjetivam a dificuldade torna-se um fator que prejudica ainda mais seus processos de aprendizagem e desenvolvimento.

A construção de diferentes formas de aprender, baseada na dimensão histórica dos sujeitos e dos processos subjetivos que a permeiam, representa um novo momento na organização teórica que defende a unidade entre cognitivo e afetivo, em que a aprendizagem é um processo inteiramente subjetivo, tanto por parte dos alunos como dos demais atores desse campo. Assim, é dada a importância de ampliar e aprofundar nos estudos acerca das produções subjetivas dos professores e suas relações com os alunos, perpassadas também por seu percurso de vida. 
Portanto, acredita-se que a interpretação histórico-cultural e a compreensão da dimensão subjetiva da aprendizagem permitiram o entendimento e estudo das dificuldades para além dos sintomas classificatórios e descritivos, abrindo assim questões para se pensar novas possibilidades de ação recuperando e valorizando aspectos subjetivos do sujeito que aprende. 


\section{ANEXO A \\ TCLE Professor}

O TDAH e as produções subjetivas da criança: problematizando o diagnóstico com pais e professores

Instituição dos(as) pesquisadores(as): Centro universitário de Brasília

Pesquisador(a) responsável [professor(a) orientador(a), graduado(a)]: Luciana de Oliveira Campolina

Pesquisador(a) assistente [aluno(a) de graduação]: Camila Zacarias Lima Araujo

Você está sendo convidado(a) a participar do projeto de pesquisa acima citado. $\mathrm{O}$ documento abaixo contém todas as informações necessárias sobre a pesquisa que estamos fazendo. Sua colaboração neste estudo será de muita importância para nós, mas se desistir a qualquer momento, isso não causará nenhum prejuízo.

O nome deste documento que você está lendo é Termo de Consentimento Livre e Esclarecido (TCLE).

Antes de decidir se deseja participar (de livre e espontânea vontade) você deverá ler e compreender todo o conteúdo. Ao final, caso decida participar, você será solicitado a assiná-lo e receberá uma cópia do mesmo.

Antes de assinar faça perguntas sobre tudo o que não tiver entendido bem. A equipe deste estudo responderá às suas perguntas a qualquer momento (antes, durante e após o estudo).

\section{Natureza e objetivos do estudo}

Os objetivos específicos deste estudo são: entender as percepções da criança que apresenta alguma dificuldade de aprendizagem atribuída pela escola ou por diagnósticos de especialistas, analisando suas interações na escola.

Você está sendo convidado a participar exatamente por ter contato com uma criança que possua um diagnóstico de TDAH, além de conhecer essa criança e compreender como são as relações dela no ambiente escolar e/ou 
familiar.

\section{Procedimentos do estudo}

Sua participação consiste em uma conversa sobre as experiências que você está vivendo com a criança que apresenta dificuldade de aprendizagem, como é pra você lidar com essas crianças dentro de sala de aula e analisar como as pessoas se relacionam com essa mesma criança. Nessas reuniões utilizarei um gravador (com a sua autorização), para não perder nenhuma informação.

A pesquisa será realizada na própria escola da criança, em salas previamente agendadas em um horário de sua disponibilidade.

\section{Riscos e benefícios}

Pelo tipo de pesquisa, informo que não haverá procedimentos que causem desconforto ou riscos ao participante. Será um momento terapêutico para conversar, pois sabemos que a relação com crianças que apresentam um déficit na aprendizagem não é simples. A orientadora desse estudo é a professora Luciana Campolina. Caso esse procedimento possa gerar algum tipo de constrangimento você não precisa realizá-lo.

Sua participação poderá ajudar no maior conhecimento acerca de como é o processo relacional para os envolvidos com uma criança que possua dificuldade de aprendizagem, além de uma compreensão de como isso se processa para você e para a escola, no ambiente educacional.

\section{Participação, recusa e direito de se retirar do estudo}

Informo que sua participação será totalmente voluntária e que você não será obrigado a fornecer informações que não queira, podendo desistir de participar dessa pesquisa a qualquer momento, sem nenhum prejuízo. Essa pesquisa será publicada, sendo que todas as informações que possam identificá-lo (a) serão omitidas.

Este trabalho pretende auxiliar você em primeiro lugar. Além disso, com essa pesquisa esperamos fornecer subsídios a todas as pessoas que lidam com esses casos. 
Conforme previsto pelas normas brasileiras de pesquisa com a participação de seres humanos você não receberá nenhum tipo de compensação financeira neste estudo.

\section{Confidencialidade}

Seus dados serão manuseados somente pelos pesquisadores e não será permitido o acesso a outras pessoas.

O material com as suas informações (fitas, entrevistas etc) ficará guardado sob a responsabilidade da professora Luciana Campolina, com a garantia de manutenção do sigilo e confidencialidade. Os dados e instrumentos utilizados ficarão arquivados com o(a) pesquisador(a) responsável por um período de 5 anos, e após esse tempo serão destruídos.

Os resultados deste trabalho poderão ser apresentados em encontros ou revistas científicas, entretanto, ele mostrará apenas os resultados obtidos como um todo, sem revelar seu nome, instituição a qual pertence ou qualquer informação que esteja relacionada com sua privacidade.

Se houver alguma consideração ou dúvida referente aos aspectos éticos da pesquisa, entre em contato com o Comitê de Ética em Pesquisa do Centro Universitário de Brasília - CEP/UniCEUB, que aprovou esta pesquisa, pelo telefone 3966.1511 ou pelo e-mail cep.uniceub@uniceub.br. Também entre em contato para informar ocorrências irregulares ou danosas durante a sua participação no estudo.

Se houver alguma consideração ou dúvida referente aos aspectos éticos da pesquisa, entre em contato com o Comitê de Ética em Pesquisa do Centro Universitário de Brasília - CEP/UniCEUB, que aprovou esta pesquisa, pelo telefone 3966.1511 ou pelo e-mail cep.uniceub@uniceub.br. Também entre em contato para informar ocorrências irregulares ou danosas durante a sua participação no estudo.

Eu, RG após receber uma explicação completa dos objetivos do estudo e dos procedimentos envolvidos concordo voluntariamente em fazer parte deste estudo. 
Este Termo de Consentimento encontra-se impresso em duas vias, sendo que uma cópia será arquivada pelo pesquisador responsável, e a outra será fornecida ao senhor(a).

Brasília, de de

Participante

Luciana de Oliveira Campolina, (61) 81195710 ou luciana.campolina@uniceub.br

Camila Zacarias Lima Araujo, (61) 81473968 ou camilazaraujo@hotmail.com

Endereço dos(as) responsável(eis) pela pesquisa (OBRIGATÓRIO):

Instituição: Centro Universitário de Brasília

Endereço: SEPN 707/907 - Campus do UniCEUB

Bloco: / No: /Complemento: Bloco 9, curso de Psicologia

Bairro: /CEP/Cidade: Asa Norte, 70790-075, Brasília

Telefones p/contato: (61) 39661200

Contato de urgência: $\operatorname{Sr}(a)$.

Domicílio: (rua, praça, conjunto)

Bloco: / No: /Complemento:

Bairro: /CEP/Cidade: /Telefone:

Ponto de referência: 


\section{ANEXO B \\ TCLE para os Pais ou Responsáveis}

O TDAH e as produções subjetivas da criança: problematizando o diagnóstico com pais e professores

Instituição dos(as) pesquisadores(as): Centro Universitário de Brasília

Pesquisador(a) responsável [professor(a) orientador(a), graduado(a)]: Luciana de Oliveira Campolina

Pesquisador(a) assistente [aluno(a) de graduação]: Camila Zacarias Lima Araujo

Você está sendo convidado(a) a participar do projeto de pesquisa acima citado. O documento abaixo contém todas as informações necessárias sobre a pesquisa que estamos fazendo. Sua colaboração neste estudo será de muita importância para nós, mas se desistir a qualquer momento, isso não causará nenhum prejuízo.

O nome deste documento que você está lendo é Termo de Consentimento Livre e Esclarecido (TCLE).

Antes de decidir se deseja participar (de livre e espontânea vontade) você deverá ler e compreender todo o conteúdo. Ao final, caso decida participar, você será solicitado a assiná-lo e receberá uma cópia do mesmo.

Antes de assinar faça perguntas sobre tudo o que não tiver entendido bem. A equipe deste estudo responderá às suas perguntas a qualquer momento (antes, durante e após o estudo).

\section{Natureza e objetivos do estudo}

Os objetivos específicos deste estudo são: investigar as produções subjetivas das crianças que apresentam alguma dificuldade de aprendizagem atribuída pela escola ou por diagnósticos de especialistas, analisando suas interações na escola; identificar os significados atribuídos pela criança à sua forma de aprender considerando os desdobramentos do diagnóstico e discutir a importância dada aos 
diagnósticos e a medicalização na sociedade atual a partir dos processos vivenciados pelas crianças.

Você está sendo convidado a participar exatamente por ter contato com uma criança que possua um diagnóstico de TDAH, além de conhecer essa criança e compreender como são as relações dela no ambiente escolar e familiar.

\section{Procedimentos do estudo}

Sua participação consiste em uma conversa sobre as experiências que você está vivendo com a criança que apresenta dificuldade de aprendizagem e analisar como as pessoas se relacionam com essa mesma criança, além de uma visão global a respeito dessa criança. Nessas reuniões utilizarei um gravador (com a sua autorização), para não perder nenhuma informação.

A pesquisa será realizada na própria escola da criança, em salas que estiverem livres.

\section{Riscos e benefícios}

Pelo tipo de pesquisa, informo que não haverá procedimentos que causem desconforto ou riscos ao participante. Será um momento terapêutico para conversar, pois sabemos que a relação com crianças que apresentam um déficit na aprendizagem não é simples. O orientador desse estudo é a Luciana Campolina. Caso esse procedimento possa gerar algum tipo de constrangimento você não precisa realizá-lo.

Sua participação poderá ajudar no maior conhecimento acerca de como se configura para os envolvidos com uma criança que possua dificuldade de aprendizagem o fato de possuir o diagnóstico, além de uma compreensão de como isso se processa para a família.

\section{Participação, recusa e direito de se retirar do estudo}

Informo que sua participação será totalmente voluntária e que você não será obrigado a fornecer informações que não queira, podendo desistir de participar dessa pesquisa a qualquer momento, sem nenhum prejuízo. Após essa pesquisa 
publicarei minha pesquisa, sendo que todas as informações que possam identificá-lo (a) serão omitidas.

Este trabalho pretende auxiliar você em primeiro lugar. Além disso, com essa pesquisa esperamos fornecer subsídios a todas as pessoas que lidam com esses casos.

Conforme previsto pelas normas brasileiras de pesquisa com a participação de seres humanos você não receberá nenhum tipo de compensação financeira pela sua participação neste estudo.

\section{Confidencialidade}

Seus dados serão manuseados somente pelos pesquisadores e não será permitido o acesso a outras pessoas.

O material com as suas informações (fitas, entrevistas etc) ficará guardado sob a responsabilidade da professora Luciana Campolina, com a garantia de manutenção do sigilo e confidencialidade. Os dados e instrumentos utilizados ficarão arquivados com o(a) pesquisador(a) responsável por um período de 5 anos, e após esse tempo serão destruídos.

Os resultados deste trabalho poderão ser apresentados em encontros ou revistas científicas, entretanto, ele mostrará apenas os resultados obtidos como um todo, sem revelar seu nome, instituição a qual pertence ou qualquer informação que esteja relacionada com sua privacidade.

Se houver alguma consideração ou dúvida referente aos aspectos éticos da pesquisa, entre em contato com o Comitê de Ética em Pesquisa do Centro Universitário de Brasília - CEP/UniCEUB, que aprovou esta pesquisa, pelo telefone 3966.1511 ou pelo e-mail cep.uniceub@uniceub.br. Também entre em contato para informar ocorrências irregulares ou danosas durante a sua participação no estudo.

$\mathrm{Eu}$, RG após receber uma explicação completa dos objetivos do estudo e dos procedimentos envolvidos concordo voluntariamente em fazer parte deste estudo. 
Este Termo de Consentimento encontra-se impresso em duas vias, sendo que uma cópia será arquivada pelo pesquisador responsável, e a outra será fornecida ao senhor(a).

Brasília, de de

Participante

Luciana de Oliveira Campolina, (61) 81195710 ou luciana.campolina@uniceub.br

Camila Zacarias Lima Araujo,(61) 81473968 e/ou camilazaraujo@hotmail.com

\section{Endereço dos(as) responsável(eis) pela pesquisa (OBRIGATÓRIO):}

Instituição: Centro Universitário de Brasília

Endereço: SEPN 707/907 - Campus do UniCEUB

Bloco: /No: /Complemento: Bloco 9, curso de Psicologia

Bairro: /CEP/Cidade: Asa Norte, 70790-075, Brasília

Telefones p/contato: (61) 39661200 


\begin{abstract}
ANEXO C
Modelo TCLE para responsáveis legais por quem não tem capacidade para decidir
\end{abstract}

O TDAH e as produções subjetivas da criança: problematizando o diagnóstico com pais e professores

Instituição dos(as) pesquisadores(as): Centro Universitário

Pesquisador(a) responsável [professor(a) orientador(a), graduado(a)]: Luciana de Oliveira Campolina

Pesquisador(a) assistente [aluno(a) de graduação]: Camila Zacarias Lima Araujo

Seu filho(a) está sendo convidado(a) a participar do projeto de pesquisa acima citado. O documento abaixo contêm todas as informações necessárias sobre a pesquisa que estamos fazendo. A colaboração dele(a) neste estudo será de muita importância para nós, mas se ele(a) desistir a qualquer momento, isso não causará nenhum prejuízo.

O nome deste documento que você está lendo é Termo de Consentimento Livre e Esclarecido (TCLE).

Antes de decidir se deseja que ele(a)participe (de livre e espontânea vontade) você deverá ler e compreender todo o conteúdo. Ao final, caso decida autorizar a participação, você será solicitado a assiná-lo e receberá uma cópia do mesmo.

Antes de assinar faça perguntas sobre tudo o que não tiver entendido bem. A equipe deste estudo responderá às suas perguntas a qualquer momento (antes, durante e após o estudo).

\title{
Natureza e objetivos do estudo
}

O objetivo específico deste estudo é compreender os aspectos da subjetividade individual e social de crianças com relação às dificuldades de aprendizagem e os impactos do diagnóstico para sua aprendizagem na escola.

\section{Procedimentos do estudo}


A participação da criança consiste em participar em duas sessões de conversação sobre seu cotidiano e suas experiências na escola, utilizando um jogo e um desenho como facilitadores do diálogo.

Os procedimentos são: estaremos presentes na sala de aula do seu filho durante 3 dias, e após esses três dias teremos encontros individuais com ele, em ambientes dentro da escola.

Para o registro da pesquisa, estarei gravando (com a sua autorização e também a autorização dele) e recolheremos os desenhos que a criança fizer ao longo dos encontros.

\section{Riscos e benefícios}

Pelo tipo de pesquisa, informo que não haverá procedimentos que causem desconforto ou riscos ao participante. Será um momento terapêutico para conversar, pois sabemos que a relação com crianças que apresentam um déficit na aprendizagem não é simples. O orientador desse estudo é a Luciana Campolina. Caso esse procedimento possa gerar algum tipo de constrangimento você não precisa realizá-lo.

A participação do seu filho poderá ajudar no maior conhecimento a respeita de como se processa, pra ele, o fato dele possuir o diagnóstico do déficit de atenção, como ele lida e se isso traz prejuízos para sua aprendizagem. Além disso, será interessante obter mais conhecimento acerca da estigmatização, se ele sente-se pressionado pelo sistema educacional vigente.

\section{Participação, recusa e direito de se retirar do estudo}

A participação é voluntária. Não terá nenhum prejuízo se você não quiser que ele(a) participe. Ele (a) poderá se retirar desta pesquisa a qualquer momento, bastando para isso entrar em contato com um dos pesquisadores responsáveis.

Conforme previsto pelas normas brasileiras de pesquisa com a participação de seres humanos, não receberá nenhum tipo de compensação financeira pela participação dele (a)neste estudo.

\section{Confidencialidade}


Os dados obtidos serão manuseados somente pelos pesquisadores e não será permitido o acesso a outras pessoas.

O material com as suas informações (fitas, entrevistas etc) ficará guardado sob a responsabilidade da professora Luciana Campolina, com a garantia de manutenção do sigilo e confidencialidade. Os dados e instrumentos utilizados ficarão arquivados com o(a) pesquisador(a) responsável por um período de 5 anos, e após esse tempo serão destruídos.

Os resultados deste trabalho poderão ser apresentados em encontros ou revistas científicas, entretanto, ele mostrará apenas os resultados obtidos como um todo, sem revelar seu nome, instituição a qual pertence ou qualquer informação que esteja relacionada com sua privacidade.

Se houver alguma consideração ou dúvida referente aos aspectos éticos da pesquisa, entre em contato com o Comitê de Ética em Pesquisa do Centro Universitário de Brasília - CEP/UniCEUB, que aprovou esta pesquisa, pelo telefone 3966.1511 ou pelo e-mail cep.uniceub@uniceub.br. Também entre em contato para informar ocorrências irregulares ou danosas durante a sua participação no estudo.

$\mathrm{Eu}$, RG após receber uma explicação completa dos objetivos do estudo e dos procedimentos envolvidos concordo voluntariamente em fazer parte deste estudo.

Este Termo de Consentimento encontra-se impresso em duas vias, sendo que uma cópia será arquivada pelo pesquisador responsável, e a outra será fornecida ao senhor(a).

Brasília, de de

Participante

Luciana de Oliveira Campolina, (61) 81195710 ou luciana.campolina@uniceub.br 
Camila Zacarias Lima Araujo, (61) 81473968 ou camilazaraujo@hotmail.com Endereço dos(as) responsável(eis) pela pesquisa (OBRIGATÓRIO): Instituição: Centro Universitário de Brasília Endereço: SEPN 707/907 - Campus do UniCEUB

Bloco: /No: /Complemento: Bloco 9, curso de Psicologia

Bairro: /CEP/Cidade: Asa Norte, 70790-075, Brasília

Telefones p/contato: (61) 39661200

Contato de urgência: $\operatorname{Sr}(a)$.

Domicílio: (rua, praça, conjunto)

Bloco: /No: /Complemento:

Bairro: /CEP/Cidade: /Telefone:

Ponto de referência: 


\section{ANEXO D \\ Termo de Aceite Institucional}

À:

\section{Cargo:}

Eu, Luciana de Oliveira Campolina, responsável pela pesquisa "O TDAH e as produções subjetivas da criança: problematizando o diagnóstico com pais e professores", junto com o(s) aluno(s) Camila Zacarias Lima Araujo solicitamos autorização para desenvolvê-la na instituição _ no período de dezembro à junho. O estudo tem como objetivo compreender as dificuldades de aprendizagem e os impactos do diagnóstico para as crianças na escola; será realizado por meio de observações, entrevista e análise de documentos; terá duas crianças com diagnóstico de TDAH, o professor e dois responsáveis pelas crianças;

Declaro que a pesquisa ocorrerá em consonância com a Resolução $n^{\circ}$ 466/12 do Conselho Nacional de Saúde e suas complementares, que regulamentam as diretrizes éticas para as pesquisas que envolvem a participação de seres humanos, ressaltando que a coleta de dados e/ou informações somente será iniciada após a aprovação da pesquisa por parte do Comitê de Ética em Pesquisa do UniCEUB (CEP-UniCEUB) e da Comissão Nacional de Ética em Pesquisa (CONEP), se também houver necessidade.

Pesquisador responsável

Pesquisador assistente 
A da escola, vem por meio deste informar que está ciente e de acordo com a realização da pesquisa nesta instituição, em conformidade com o exposto pelos pesquisadores.

Brasília-DF, de de

Nome e carimbo com o cargo do representante da instituição onde será realizado o projeto 


\section{REFERÊNCIAS}

BEZERRA, Marilia Santos. Dificuldades de aprendizagem e subjetividade: Para além das representações hegemônicas do aprender. 157f. Dissertação de Mestrado - Universidade de Brasília, Brasília, 2014.

CAMPOLINA, Luciana Oliveira. Aprendizagem, subjetividade e interações sociais na escola. MITÁNJS MARTÍNEZ, Albertina; ÁLVAREZ, Patrícia. (Orgs), O sujeito que aprende: diálogo entre a psicanálise e o enfoque histórico-cultural. Brasília: Liber Livro, 2014, 179-212.

GONZÁLEZ REY, Fernando. Pesquisa Qualitativa e Subjetividade: Os processos de construção da informação. São Paulo: Cengage Learning, 2005.

GONZÁLEZ REY, Fernando. Subjetividade e Saúde: superando a clínica da patologia. São Paulo: Cortez, 2011.

GONZÁLEZ REY, Fernando; MITJÁNS MARTÍNEZ, Albertina. Psicologia, Educação e Aprendizagem Escolar: avançando na contribuição da leitura histórico-cultural. São Paulo: Cortez, 2017.

GOULART, Daniel Magalhães; ALCÂNTARA, Raquel. Educação escolar e subjetividade: desafios contemporâneos. United States: GlobalSouth, 20016.

LANDSKRON, Lílian Marx Flor; SPERB, Tania Mara. Narrativas de professoras sobre o TDAH: um estudo de caso coletivo. Revista Semestral da Associação Brasileira de Psicologia Escolar e Educacional (ABRAPEE), Rio Grande do Sul, v.12, n. 1, p. 153-167, jan/jun 2008.

MARTINS, João Batista. Observação participante: uma abordagem metodológica para a psicologia escolar. Ci. Sociais/Humanas, Londrina, v.17, n. 3, p. 266-273, set 1996

MITJÁNS MARTÍNEZ, Albertina. Inclusão escolar: desafios para o psicólogo. In MITJÁNS MARTÍNEZ, Albertina. (Org.). Psicologia escolar e compromisso social: novos discursos, novas práticas. Campinas: Alínea, 2007, p. 95-114.

MITJÁNS MARTINEZ, Albertina; TACCA. Maria Carmen Villela Rosa.

Possibilidades de aprendizagem: ações pedagógicas para alunos com dificuldade e deficiência. São Paulo: Alínea, 2011.

MORI, Valeria Deusdará; GONZÁEZ REY, Fernando. Reflexões sobre o social e o individual na experiência do câncer. Psicologia \& Sociedade, Brasília, v. 23 n. spe,p. 99-108, 2011.

POPOVIĆ, Marinês Bortolete. Para além da doença inflamatória intestinal: subjetividade, sentidos subjetivos e modo de vida de um paciente. 2015. $53 \mathrm{f}$. Monografia não publicada - Centro Universitário de Brasília, Brasília, 2015.

POZO, Juan Ignácio. Aprendizes e mestres: a nova cultura da aprendizagem. Porto Alegre: Artmed, 2002. 
RAAD, Ingrid Lilian Fuhr. Deficiência como iatrogênese: a medicina, a família e a escola como cúmplices no processo do adoecimento. 2007. 83f. Dissertação de Mestrado não publicada -Universidade de Brasília, Brasília, 2007.

SILVA, Giselle de Fátima. Os sentidos subjetivos de adolescentes com câncer. 2008.165f. Mestrado - Pontifícia Universidade Católica de Campinas, Campinas, 2008.

SOUSA, Sandra Zákia Lian. O caráter discriminatório da avaliação do rendimento escolar. Revista Adusp, n. 2,p. 15-17, abr. 1995.

SOUZA, Bruna Regina Andrade. Processos educativos: subjetividade e saúde. 60f. Monografia não publicada - Centro Universitário de Brasília, Brasília, 2013.

VASCONCELOS, Marcio al. Contribuição dos fatores de risco psicossociais para o transtorno de déficit de atenção/hiperatividade. Arq Neuropsiquiatr,São Paulo $v$. 63, n.1, p. 68-74, mar 2005. 